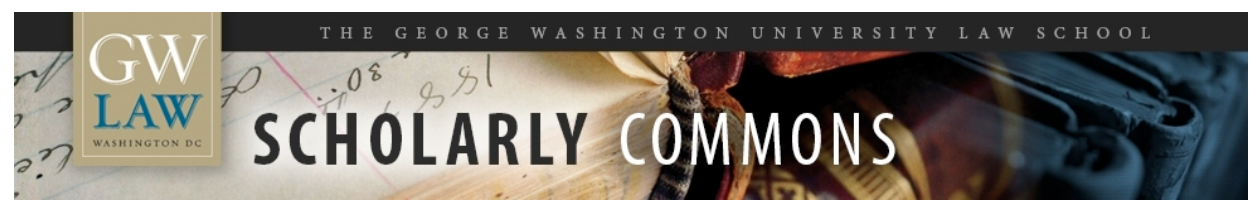

GW Law Faculty Publications \& Other Works

2020

\title{
Administrative Investigations
}

Aram A. Gavoor

Steven Platt

Follow this and additional works at: https://scholarship.law.gwu.edu/faculty_publications

Part of the Law Commons 
ADMINISTRATIVE INVESTIGATIONS

(C) 2021 Aram A. Gavoor ${ }^{\dagger} \&$ Steven A. Platt*

\begin{abstract}
This Article establishes the subject of federal administrative investigations as a new area of study in administrative law. While the literature has addressed investigations by specific agencies and congressional investigations, there is no general account for the trans-substantive constitutional value of administrative investigations. This Article provides such an account by exploring the positive law, agency behaviors, and constraints pertaining to this unresearched field. It concludes with some urgency that the Administrative Procedure Act of 1946-the statute that stands as a bill of rights for the Administrative State-does not serve to regulate administrative investigations and that the Article III courts have held that such agency behavior is essentially unreviewable since the mid-twentieth century. It identifies the historical guideposts of administrative investigations and analyzes the substantial power agencies wield when they investigate. It surveys and analyzes the limiting principles in law that operate as nominal constraints to unlawful administrative investigative behavior. This Article concludes by considering procedural and substantive constraints that could be implemented to align agency investigations with constitutional and statutory norms without sacrificing their ability to fulfill their critical missions for the American public.
\end{abstract}

\footnotetext{
$\dagger$ Professorial Lecturer of Law, The George Washington University Law School. The authors thank Sam Bray, Ron Cass, David Fischer, Kristin Hickman, Ted Hirt, Ben Johnson, Dick Pierce, David Rubenstein, Jon Siegel, and Chris Walker for their advice and comments, and David Byerley for his research assistance.

$\$$ J.D., University of Minnesota Law School, B.A., The University of Iowa; former law clerk to the Hon. D. Gregory Kays, U.S. District Judge for the Western District of Missouri.
} 


\section{TABLE OF CONTENTS}

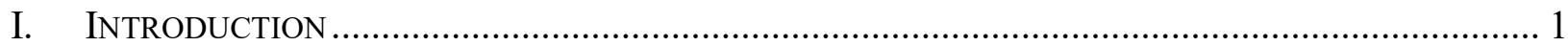

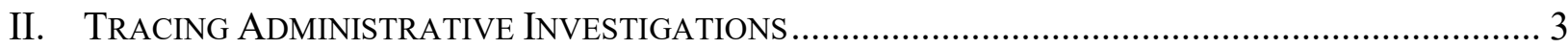

A. Supreme Court Treatment of Agency Investigations ....................................................... 3

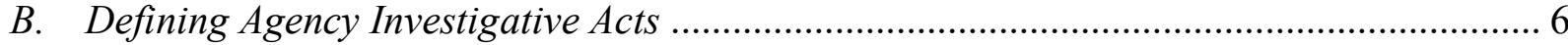

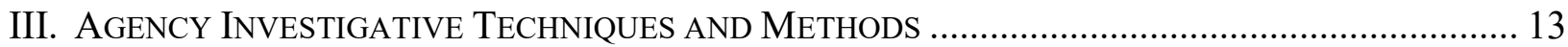

IV. CONSTRAINTS ON AGENCY INVESTIGATIONS ......................................................................... 16

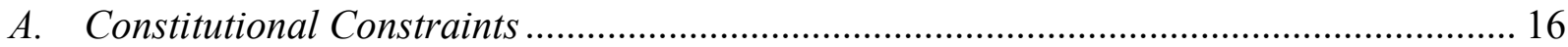

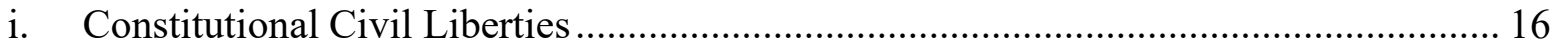

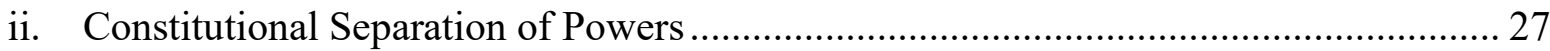

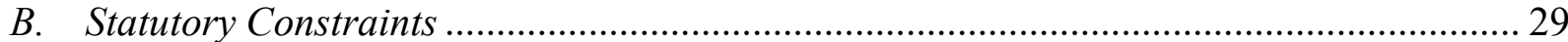

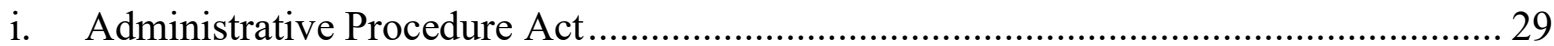

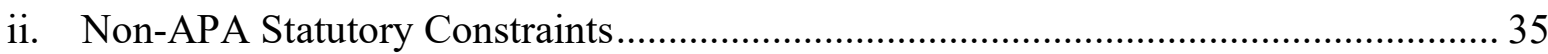

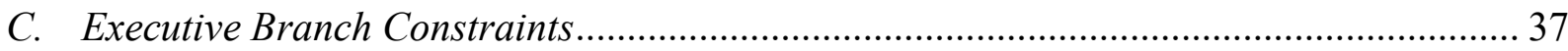

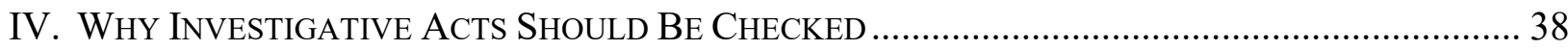

A. The Benefits of Agency Civil Investigative Behavior ........................................................ 38

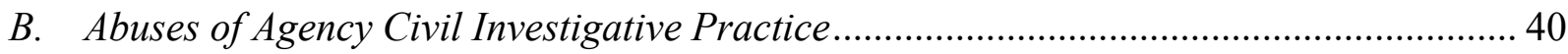

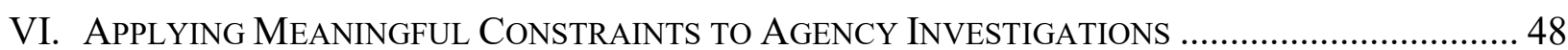

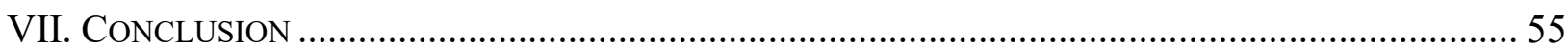




\section{INTRODUCTION}

Almost uniformly, federal agencies investigate. Armed with broad or vague mandates, agencies investigate matters within their purview that they might be able to enforce or regulate. This domain is shrouded in considerable mystery. The final agency action following an investigation does not always disclose the full extent of the agency's inquiry. If agencies decline to act on the results of an investigation, the public will likely never know that it took place, aside from the targets of the investigation or third parties who receive agency requests for information under the threat of compulsion, such as subpoenas or warrants.

The full extent of an agency investigation can be fearsome. The Federal Trade Commission ("FTC") doggedly investigated a company called LabMD, which cost the business millions to defend and ultimately caused its shuttering. ${ }^{1}$ Under the strain of a multiyear FTC investigation, LabMD saw its revenue halved over the course of a year and its insurers refuse to renew the company's policies. ${ }^{2}$ In January 2014, the CEO shut down the company due to the "psychological warfare the FTC did on the company," which included hammering LabMD with continual demands which relented only upon settlement. ${ }^{3}$ Part of the cost to LabMD came from protracted litigation spurred by allegedly falsified information that a cyber-security firm gave the government, ${ }^{4}$ and allegations that a Big Law firm covered up for that firm. ${ }^{5}$ A House Oversight Committee report later concluded that the FTC had sacrificed "good government" in using a conflicted third party's leads to "obtain information validating its regulatory authority" and providing the third party with "actionable information that it exploited for monetary gain." 6

Whether deployed nobly or not, agency investigative tools are powerful and merit examination. This Article reveals and probes federal agency investigations, their legal foundation and constraints, and how the People can act to improve agency behavior. Our nuanced inquiry into administrative investigations is the first of its kind. ${ }^{7}$ Despite the richness,

${ }^{1}$ Dune Lawrence, A Leak Wounded This Company. Fighting the Feds Finished It Off, BloOMBERG BusinessweEK (Apr. 25, 2016), https://www.bloomberg.com/features/2016-labmdftc-tiversa/.

${ }^{2} I d$.

${ }^{3} I d$.

${ }^{4}$ Joel Schectman, Exclusive: DOJ Probes Allegations that Tiversa Lied to FTC about Data Breaches, REUTERS (Mar. 17, 2016), https:/www.reuters.com/article/us-tiversa-doj-probeexclusive-idUSKCN0WK027.

${ }^{5}$ Kathryn Rubino, Biglaw Firm Accused of Covering Up for Hacker, ABOVE THE LAW (May 8, 2018), https://abovethelaw.com/2018/05/biglaw-firm-accused-of-covering-up-for-hacker/.

${ }^{6}$ Lawrence, supra note 1; see also Alison Frankel, There's a Big Problem for the FTC Lurking in 11th Circuit's LabMD Data-Security Ruling, REUTERS (June 7, 2018), https://www.reuters.com/article/us-otc-labmd/theres-a-big-problem-for-the-ftc-lurking-in-11thcircuits-labmd-data-security-ruling-idUSKCN1J32S2.

${ }^{7}$ The last article that appears to have addressed the general topic of agency investigations was written in 1985. John W. Bagby, Administrative Investigations: Preserving a Reasonable Balance Between Agency Powers and Target Rights, 23 AM. Bus. L.J. 319 (1985). Professor 
ubiquity, and importance of administrative investigations, it has never been studied in depth. Others have obliquely touched on the some of the topics that this Article squarely addresses. ${ }^{8}$ The Supreme Court has recently addressed the scope of administrative warrants and subpoenas, ${ }^{9}$ but it has not examined the foundation of its modern jurisprudence for evaluating the lawfulness of agency investigations or to develop a touchstone for agencies and the public. Instead, the Court catalyzed the flourishment of a highly deferential standard that rarely results in the quashing of agency investigative action or the exercise of agency self-restraint. The Court has also refrained from acknowledging that the foundations of its earlier cases have been eroded by more recent developments in both constitutional law and administrative law.

Our research has led us to conclude that courts are not using the Fourth Amendment to meaningfully rein in agency investigative excesses, and that courts are not using the Administrative Procedure Act of 1946 ("APA") at all to regulate agency investigative behavior. Courts have consistently held that investigative behavior is unreviewable for lack of finality. The following chart displays how administrative investigations are not constrained by positive procedures or judicial review under the APA.

\begin{tabular}{|l|c|c|c|c|c|c|}
\hline \multicolumn{7}{|c|}{$\begin{array}{l}\text { Judicially Recognized Positive APA Procedures and Article III Review of Administrative Behaviors } \\
\text { (all citations to title 5 U.S. Code) }\end{array}$} \\
\hline & $\begin{array}{c}\text { Investigative } \\
\text { Behavior/Action }\end{array}$ & $\begin{array}{c}\text { Informal } \\
\text { Adjudication } \\
\text { \& Licensure }\end{array}$ & $\begin{array}{c}\text { Formal } \\
\text { Adjudication } \\
\& \text { Licensure }\end{array}$ & $\begin{array}{c}\text { Subregulatory } \\
\text { Rulemaking }\end{array}$ & $\begin{array}{c}\text { Informal } \\
\text { Legislative } \\
\text { Rulemaking }\end{array}$ & $\begin{array}{c}\text { Formal } \\
\text { Legislative } \\
\text { Rulemaking }\end{array}$ \\
\hline $\begin{array}{l}\text { Positive } \\
\text { procedures? }\end{array}$ & $N^{10}$ & $\begin{array}{c}\text { No, save for } \\
\S 555(\mathrm{e})^{11}\end{array}$ & $\begin{array}{c}\S 554,556, \\
557\end{array}$ & $\S 553$ & $\S 553$ & $\S 553,556$, \\
\hline $\begin{array}{l}\text { Reviewable } \\
\text { under } \S 704 ?\end{array}$ & Rarely & Yes & Yes & Yes & Yes & Yes \\
\hline
\end{tabular}

Philip Hamburger has discussed "Inquisitorial Process" and "Prerogative Orders and Warrants" in a historical lens, but has not engaged on this general topic. Philip Hamburger, Is Administrative Law Unlawful? 157-90 (2014). See also, Mila Sohoni, Crackdowns, 31 VA. L. REV. 31 (2017) (on enforcement discretion); Zachary Price, Enforcement Discretion and Executive Duty, 67 VAND. L. REV. 671 (2014) (same).

${ }^{8}$ See, e.g., Michael Asimow, Federal Administrative AdjudicAtion Outside THE AdMINISTRATIVE PROCEDURE ACT (2019), https://www.acus.gov/sites/default/files/documents/Federal\%20Administrative\%20Adj\%20Outsi de\%20the\%20APA\%20-\%20Final.pdf.

${ }^{9}$ See, e.g., McLane Co. v. EEOC, 137 S. Ct. 1159, 1166-70 (2017) (holding that a district court's decision to enforce or quash an Equal Employment Opportunity Commission administrative subpoena is reviewed for abuse of discretion, not de novo, with reference to "longstanding practice of the courts of appeals in reviewing a district court's decision to enforce or quash an administrative subpoena").

${ }^{10}$ No federal court has held that administrative investigative behavior is reviewable on its face.

${ }^{11}$ Butte Cty. v. Hogen, 613 F.3d 190, 194 (D.C. Cir. 2010) (concluding that under 5 U.S.C. $\S 555(\mathrm{e})$, "the agency must provide an interested party . . . with a brief statement of the grounds for denial" in an informal adjudication). 
This Article first analyzes the evolution of the Supreme Court's treatment of investigative actions and concludes that the U.S. Constitution provides no meaningful barrier to such exercises of investigative power. It identifies and analyzes how the APA never regulated the civil investigative conduct of agencies. To aid this Article's navigation into these uncharted waters, Part II looks into the history of agency investigations to see whether and how they have been constrained. Here we fashion a working definition to use as a foundation for our examination. Part III surveys the range of agency investigative techniques and showcases the degree of power agencies wield when they investigate.

Part IV analyzes the efficacy of checks on agency investigatory abuses. These checks manifest in hard and soft forms. Hard constraints, like the APA and the Bill of Rights, provide direct avenues for inappropriately-investigated individuals to seek judicial redress. Soft constraints, like the separation of powers principle of the Constitution and Congress's powers of oversight and the purse, merit discussion but are less directly able to contain abusive investigations. Likewise, the exercise of executive branch self-restraint is a suboptimal solution due to a durability deficit. Our research leads us to conclude that there are minimal barriers applied throughout the federal government under the innumerable administrative statutory schemes that facilitate investigations and that any enlargement of prosecutorial behavior in light of new technologies could evolve to an unanticipated and unprecedented total enforcement environment in portions of administrative law.

To assess the desirability of heightened barriers, Part V examines how administrative investigations further the purpose of agencies in the constitutional order. Proceeding from the conclusion that adequate restraints are lacking, this Part establishes why checks are needed on investigative actions by chronicling abuses and inefficiencies in agency investigations.

Part VI identifies and analyzes potential solutions to unlawful investigative acts that could be utilized to calibrate agency investigations into constitutional and statutory norms without foreclosing agencies' ability to lawfully execute their respective missions.

\section{TRACING AdMinistrative InVESTIGATIONS}

\section{A. Supreme Court Treatment of Agency Investigations}

As long as there has been civilized government, there has been executive investigation. ${ }^{12}$ The concept of administrative investigations draws from this legacy. ${ }^{13}$ In medieval England, the

121 Samuel 14:38 ("Saul said, 'Draw near here, all you chiefs of the people, and investigate and see how this sin has happened today."').

${ }^{13}$ Kenneth Culp Davis, The Administrative Power of Investigation, 56 Y ALE L.J. 1111, 1111-14 (1947) (beginning in biblical times and continuing through World War II and noting, "The story of the development of the administrative power of investigation is rather dramatic."). 
King's chancellor, an administrative official, commonly issued writs as royal commands. ${ }^{14}$ During the seventeenth century, the powerful Star Chamber issued broad warrants permitting searches of the papers of political suspects. ${ }^{15}$ Eighteenth-century England exercised administrative power in the form of general warrants, writs of assistance (e.g., authorizing customs searches). ${ }^{16}$ In colonial America, writs of assistance - that is, general search warrantswere a major grievance that spurred the colonies to declare independence. ${ }^{17}$

One of the first statutes explicitly authorizing agency investigations was the act creating the Steamboat Inspection Service in $1838,{ }^{18}$ followed by the Interstate Commerce Commission Act in 1887. ${ }^{19}$ The courts struggled with what oversight to exercise over agency investigations. ${ }^{20}$ The Supreme Court initially viewed with skepticism agencies' ability to issue subpoenas, even upon congressional delegation. ${ }^{21}$ The majority opinion in Harriman v. Interstate Commerce Commission limited administrative subpoenas to "the cases where the sacrifice of privacy is necessary - those where the investigations concern a specific breach of law." 22 The Court reinforced the notions that agency investigative acts would be scrutinized carefully, by denouncing a "general, roving, offensive, inquisitorial, compulsory investigation, conducted by a commission without any allegations, upon no fixed principles, and governed by no rules of law, or of evidence, and no restrictions except its own will, or caprice." ${ }^{23}$ Into the 1920s, the Court

${ }^{14}$ John A. Hamill, Sr., EPA Administrative Investigative Tools: An Inside Perspective, 4 J. ENVTL. L. \& LiTIG. 85, 86-87 (1989) (discussing how writs were "an executive, not a judicial, invention," arising after the Norman conquest of 1066 and commonly issued by the King's chancellor and other administrative officials).

15 Osmond K. Fraenkel, Concerning Searches and Seizures, 34 HARV. L. REV. 361, 362 (1921).

${ }^{16}$ Philip Hamburger, Early Prerogative and Administrative Power: A Response to Paul Craig, 81 Mo. L. REV. 939, 952 (2016).

${ }^{17}$ Davis, supra note 13, at 1111-14.

185 Stat. 304 (1838). This act provided for inspections of hulls, boilers, and the like. Id. §§ 3-6; see Jerry L. Mashaw, Administration and "The Democracy": Administrative Law from Jackson to Lincoln, 1829-1861, 117 YALE L.J. 1568, 1633 (2008).

${ }^{19}$ Kristin E. HickMAN \& Richard J. PierCe, JR., Administrative LAW TREATISE $§ 8.1$ (6th ed. 2019) (citing 24 Stat. 379, 383 (1887)).

${ }^{20}$ Mariano-Florentino Cuéllar, Administrative War, 82 GEO. WASH. L. REV. 1343, 1401-08 (2014); Donald R.C. Pongrace, Requirement of Notice of Third-Party Subpoenas Issued in SEC Investigations: A New Limitation on the Administrative Subpoena Power, 33 AM. U. L. REV. 701, 709-16 (1984) (discussing how the Supreme Court initially erected a high hurdle for agencies to issue administrative subpoenas); HICKMAN \& PIERCE, supra note $19, \S 8.1$ (similar).

${ }^{21}$ Donald R.C. Pongrace, Requirement of Notice of Third-Party Subpoenas Issued in SEC Investigations: A New Limitation on the Administrative Subpoena Power, 33 AM. U. L. REV. 701, 709-10 (1984).

${ }^{22}$ Harriman v. Interstate Commerce Comm'n, 211 U.S. 407, 419-20 (1908).

${ }^{23}$ Jones v. SEC, 298 U.S. 1, 27 (1936) (quoting In re Pac. Ry. Comm'n, 32 F. 241, 263

(C.C.N.D. Cal. 1887)). 
reiterated its disapproval of "fishing expeditions into private papers on the possibility that they may disclose evidence of crime. ${ }^{24}$

But the Supreme Court's attitude shifted after the New Deal established new and varied agencies with complex missions. ${ }^{25}$ After World War II, and in near-contemporaneity with the enactment of the Administrative Procedure Act of 1946, the Court decided a body of cases that recalibrated the baseline judicial scrutiny of agency investigations as highly deferential. These seminal cases — which are examined in depth by this Article_-include Oklahoma Press Publishing Co. v. Walling ${ }^{26}$ and United States v. Morton Salt Co. ${ }^{27}$

In Oklahoma Press Publishing, the U.S. Department of Labor's Wage and Hour Division issued subpoenas to two newspaper publishers it was investigating for violating the Fair Labor Standards Act. ${ }^{28}$ The publishers resisted the subpoenas, arguing that the Division failed to comply with the Fourth Amendment and demonstrate the probable cause necessary to enforce the subpoenas. ${ }^{29}$ The Supreme Court rejected that argument and dismissed the publishers' concerns about executive "general fishing expeditions into [their] books, records and papers, in order to secure evidence that they have violated the Act," holding that "the records in these cases present no question of actual search and seizure" but were only "constructive" searches. ${ }^{30}$ For such constructive searches, the Fourth Amendment's probable cause requirement was satisfied simply "by the court's determination that the investigation is authorized by Congress, is for a purpose Congress can order and the documents sought are relevant to the inquiry." 31 Oklahoma Press Publishing thus ruled that the Fourth Amendment protects regulated parties only so far as Congress has explicitly limited agencies' subpoena authorities. ${ }^{32}$ Because the Fair Labor Standards Act's "language leaves no room to doubt that Congress intended to authorize just what the Administrator did and sought have the courts do," the publishers' claims failed. ${ }^{33}$ The opinion also took particular note of the "corporate character" of the publishers' records, implying that the Fourth Amendment's protections were especially attenuated in that circumstance. ${ }^{34}$ Justice Murphy dissented alone, inveighing against all uses of administrative subpoenas and alluding to King George III as he worried administrative subpoenas were vulnerable to "[e]xcessive use or abuse of authority." 35

The Supreme Court returned to review the lawfulness of agency warrants four years later in Morton Salt Co., this time in a challenge to a Federal Trade Commission order requiring salt

${ }^{24}$ FTC v. Am. Tobacco Co., 264 U.S. 298, 306 (1924).

${ }^{25}$ Davis, supra note 13, at 1122.

${ }^{26}$ Okla. Press Pub'g Co. v. Walling, 327 U.S. 186, 209 (1946).

${ }^{27}$ United States v. Morton Salt Co., 338 U.S. 632, 652 (1950).

${ }^{28}$ Okla. Press Pub'g Co., 327 U.S. at 189.

${ }^{29} \mathrm{Id}$. at $189-90$.

${ }^{30} \mathrm{Id}$. at $194-95,202-05$.

${ }^{31} \mathrm{Id}$. at 209.

${ }^{32}$ Id. at 197-202.

${ }^{33} \mathrm{Id}$. at 198.

${ }^{34} \mathrm{Id}$. at $204-08$.

${ }^{35} I d$. at 218-19 (Murphy, J., dissenting). 
producers and trade associations to file various and comprehensive reports and statements. ${ }^{36}$ The salters argued that the Commission's order violated the Fourth and Fifth Amendments. ${ }^{37}$ Building off of Oklahoma Press Publishing, including its dim view of the robustness of business associations' constitutional rights in this context, the Court held that "neither incorporated nor unincorporated associations can plead an unqualified right to conduct their affairs in secret." 38 "Of course," the Court recognized, the Constitution imposes some limits on what the Commission could demand. ${ }^{39}$ In addition to the limitations found in Oklahoma Press Publishing - that the type of agency request must be authorized by statute and the specific agency request must be "reasonably relevant"- the Supreme Court held that "the demand [must be] not too indefinite." 40 The Court summarily found that the Commission's order, on its face, met those standards. ${ }^{41}$ Finally, the Court faulted the salters for not complaining directly to the Commission and asking it to modify the order: before quashing agency investigative acts as "arbitrarily excessive," courts "may expect the supplicant to have made reasonable efforts before the Commission itself to obtain reasonable conditions." 42

These two decisions had the effect of "further legitimizing the routine use of administrative subpoenas." 43 This regime was ushered in by new Justices with a more hospitable view of government intervention. ${ }^{44}$ The Supreme Court has not in recent years squarely addressed this issue or the standards that should apply to judicial review of agency investigatory techniques. ${ }^{45}$ Although the Supreme Court has not in recent years taken up the matter squarely, it has not done so for a lack of petitions for a writ of certiorari. Several have been filed in the years since Morton Salt, asking the Court to overrule or diminish parts of that jurisprudence. ${ }^{46}$

\section{B. Defining Agency Investigative Acts}

The postwar Supreme Court cases involve perhaps the quintessential agency investigative act, subpoenas. But subpoenas are just one example of an agency investigative act. A proper study of investigations requires us to define what agency investigative acts are, precisely. The academy and courts have not coalesced on a comprehensive definition of an agency investigative act. The Attorney General's 1941 report on administrative procedure remarked, "Much that

${ }^{36}$ United States v. Morton Salt Co., 338 U.S. 632, 636-37 (1950).

${ }^{37}$ Id. at 651 .

${ }^{38} I d$. at 652 .

${ }^{39} \mathrm{Id}$. at 652,653 .

${ }^{40} \mathrm{Id}$. at 652 .

${ }^{41} I d$. at 653 .

${ }^{42} I d$.

${ }^{43}$ Cuéllar, supra note 20, at 1404.

${ }^{44}$ HICKMAN \& PIERCE, supra note $19, \S 8.1$.

${ }^{45}$ See, e.g., id. $\$ 8.2$.

${ }^{46}$ See, e.g., Pet. for Writ of Certiorari, Koresko v. Chao, 2006 WL 1455400 (2006) (“Morton Salt and Powell are decades old, predating this Court's jurisprudence on privacy rights. Subsequent statutory law has worn away the main thread of the holdings - that government inquiries must be presumed legitimate."). 
occurs at a hearing or conference is conditioned by the investigation of the problem which may have preceded it, or of which the hearing may be a part." 47 Once Congress enacted the APA, which carried forward many existing administrative law practices, Professor Kenneth Culp Davis offered, "The Administrative Procedure Act to the contrary notwithstanding, administrative proceedings are not limited to rule-making, adjudication, and licensing. Some administrative proceedings are investigations_-proceedings designed to produce information." 48

The Supreme Court has weighed in by providing a negative definition of an administrative investigation, concluding that an investigation is not a final agency action. ${ }^{49}$ An investigation "is not a definitive statement of position ... [but only] represents a threshold determination that further inquiry is warranted ..."50 The APA obliquely references "nonpublic investigatory proceeding[s]" and "investigative act[s]," 51 but "provides no statutory definition or classification of different kinds of investigations." 52

Nor do dictionaries provide helpful definitions. Webster's defines "investigate" - and the word's derivatives, "investigatory," "investigator," and "investigation" - to mean "a systematic examination." 53 Other courts have turned to Black's Law Dictionary's definition, which focuses on the objective of the investigation: "[ $\mathrm{t}]$ he activity of trying to find out the truth about something." 54 The Department of Justice has defined "regulatory investigations" similarly: “"[R] egulatory investigations'... generally have as their objective regulatory compliance by private parties." 55 This demonstrates a parallel framework to Justice Stewart's "I know it when I see it" approach. ${ }^{56}$

Although there is no general, executive branch definition of administrative investigation, certain organic statutes give agencies binding definitions in some contexts. For example, the Antitrust Civil Process Act provides: “[t]he term 'antitrust investigation' means any inquiry conducted by any antitrust investigator for the purpose of ascertaining whether any person is or

\footnotetext{
47 Attorney General's Committee on Administrative Procedure, Department of JUSTICE 111 (1941).

${ }^{48}$ Davis, supra note 13, at 1111; see also David C. Shonka, Responding to the Government's Civil Investigations, 15 SEDONA CONF. J. 1, 1 (2014).

${ }^{49}$ FTC v. Std. Oil Co. of Cal., 449 U.S. 232, 241 (1980).

${ }^{50} \mathrm{Id}$.

515 U.S.C. $\$ \S 555(\mathrm{c}), 554(\mathrm{~d})$.

52 John A. Hamill, Sr., EPA Administrative Investigative Tools: An Inside Perspective, $4 \mathrm{~J}$. ENVTL. L. \& LiTIG. 85, 88 (1989) (footnotes omitted).

${ }^{53}$ Doe v. Rogers, 139 F. Supp. 3d 120, 137-38 (D.D.C. 2015).

${ }^{54}$ MusclePharm Corp. v. Liberty Ins. Underwriters, Inc., 712 F. App'x 745, 755 (10th Cir. 2017) (citing Black's Law Dictionary (10th ed. 2014) and distinguishing "regulatory investigation" from "proceeding.").

${ }^{55}$ U.S. Department of Justice, Office of Legal Counsel, Inspector General Authority to Conduct Regulatory Investigations, 13 U.S. Op. Off. Legal Counsel 54, 54 n.1, 1989 WL 595865, at*1 n.1 (Mar. 9, 1989).

56 Jacobellis v. Ohio, 378 U.S. 184, 197 (1964) (Stewart, J. concurring) (applying such an approach to pornography).
} 
has been engaged in any antitrust violation or in any activities in preparation for a merger, acquisition, joint venture, or similar transaction, which, if consummated, may result in an antitrust violation." 57 Similar statutory definitions for civil administrative investigation exist for the Consumer Financial Protection Bureau ("CFPB") ${ }^{58}$ and the Federal Trade Commission ("FTC"). ${ }^{59}$ These definitions, too, are only general.

We thus offer a definition of agency investigative acts: Executive branch agency exercises of civil examination or inquiry authority, taken in the absence of positive APA procedures, that carry the perceived, eventual, or actual threat of compulsion. ${ }^{60} \mathrm{We}$ draw the term from the APA, which uses it, albeit glancingly and without definition. ${ }^{61}$

Deconstructing such definition requires mapping agency behavior that precedes "agency action" as normatively understood in the APA in 5 U.S.C. $\S 704 .^{62}$ The agency must be acting on some kind of formal or informal complaint, tip, internal targeting, or a defined trigger point, at which point the agency researches the facts necessary to sustain an agency action and decides whether to initiate such an action. ${ }^{63}$ If the type of agency action is an adjudication, then the investigation could enable the decision whether to adjudicate by enforcement against a specific party. Here, investigation targets are not (yet) respondents or defendants in agency or civil actions, but akin to third-party witnesses, including third-party witnesses on notice of their potential status as a party-defendant. ${ }^{64}$ The goal is to determine whether agency action that would trigger normative $\S 704$ finality is warranted.

Our definition presumes that the purpose of agency investigation is to see whether some agency action may eventually be warranted, excepting when the investigation is preordained to produce a discrete outcome. This comports with the Supreme Court's 1946 statement that agency investigations aim to "discovery and procure evidence" to see if that evidence "should justify" bringing a charge or complaint. ${ }^{65}$ It also comports with the Court's later distinction

${ }^{57} 15$ U.S.C. $\$ 1311(\mathrm{c})$.

58 12 U.S.C. $\$ 5561$. The Supreme Court held that it was unconstitutional for the CFPB's director to be removed only for cause. See Seila Law LLC v. Consumer Prot. Bureau, $140 \mathrm{~S}$. Ct. 2183 (2020). Although the case focused primarily on the authorities of inferior officers of the United States, it arose in the context of CFPB attempting to enforce its civil investigatory authority against the respondent. $I d$. at *6-7.

59 15 U.S.C. $\$ 57 \mathrm{~b}-1$.

60 This definition comports with the only other attempted definition in the literature of which we are aware, Professor Davis's comment that investigations are "designed to produce information." Davis, supra note 13, at 1111.

615 U.S.C. $\S 555(\mathrm{c})$.

${ }^{62}$ Asimow, supra note 8.

${ }^{63}$ E.g., 7 U.S.C. $\S 193$ (a) (describing the procedure for the Department of Agriculture to investigate, hear, and fine packers and swine contractors who have violated or may have violated the Packers and Stockyards Act of 1921").

${ }^{64}$ FTC v. Compagnie De Saint-Gobain-Pont-a-Mousson, 636 F.2d 1300, 1310-11 (D.C. Cir. 1980).

${ }^{65}$ Okla. Press Pub'g Co. v. Walling, 327 U.S. 186, 201 (1946). 
between "determinations of a quasi-judicial nature" - i.e., adjudications - and "nonadjudicative, fact-finding investigations." 66 This definitional prong leaves out agency movement where agency action is remote, impossible, or forsworn. For example, when the government seeks demographic data for the decennial census, the request's purpose is not to make agency action. ${ }^{67}$

A variety of sources can spark an investigation. Some agencies could conduct an investigation as an exercise of its own discretion and on its own initiative. For example, the CFPB may issue civil investigative demands to collect information "before the institution of any proceedings." ${ }^{68}$ The agency might do so simply upon reading a news story, ${ }^{69}$ or just "merely on suspicion."70 The agency might receive a tip or notification, perhaps from an inspector general or another federal agency like the Department of Justice. ${ }^{71}$ This may be because a private party files a charge with the agency and the agency is required to investigate (often within a timeframe) whether to file an administrative complaint. ${ }^{72}$ The agency may commence an investigation upon direction from the President. ${ }^{73}$ Congress may also issue a directive to investigate, ${ }^{74}$ for example, through a statute directing an agency to adopt rules within a certain number of days on a particular subject, which requires the agency to investigate what the rule should be. ${ }^{75}$

\footnotetext{
${ }^{66}$ Hannah v. Larche, 363 U.S. 420, 445-46 (1960).

${ }^{67}$ See 13 U.S.C. $\S \S 141,181$ (authorizing the Census Bureau to conduct decennial censuses and interim inquiries).

6812 U.S.C. $\$ 5562(\mathrm{c})(1)$. Each demand must "state the nature of the conduct constituting the alleged violation which is under investigation and the provision of law applicable to such violation." Id. § 5562(c)(2).

${ }^{69}$ Shonka, supra note 48, at 2.

${ }^{70}$ United States v. Powell, 379 U.S. 48, 57 (1964).

${ }^{71}$ E.g., FeD. EleCtion COMM’N, GUIDEBOOK FOR COMPLAINANTS AND RESPONDENTS ON THE FEC ENFORCEMENT PROCESS 8-9 (2012), https://transition.fec.gov/em/respondent_guide.pdf. 728 U.S.C. $\S 1324 b(d)(2)$ (the U.S. Department of Justice’s Civil Rights Division's Immigrant and Employee Rights Section, which receives and investigates complaints of unfair immigrationrelated employment practices); see also id. $\S 1324 \mathrm{~b}(\mathrm{~d})(1)$ (also permitting that Section to unilaterally investigate and file charges); 14 C.F.R. $§ 13.5(\mathrm{~g})-(\mathrm{i})$ (similar, for Federal Aviation Administration complaints); 52 U.S.C. § 30109(a)(1); 11 C.F.R. § 111.4 (similar, for FEC complaints); 29 U.S.C. $§ 160$ (b) (similar, for National Labor Relations Board complaints). ${ }^{73}$ E.g., Zeke Miller, President Trump Orders Intelligence Agencies to 'Fully Cooperate' With Investigation into Mueller Probe, TIME (May 24, 2019), https://time.com/5595248/donaldtrump-intelligence-russia/; Kaveh Waddell, Obama Orders Investigation into Election-Related Hacking, THE ATLANTIC (Dec. 9, 2016), https://www.theatlantic.com/technology/archive/2016/12/obama-orders-full-review-of-electionrelated-hacking/510149/.

${ }^{74}$ Shonka, supra note 48, at 2.

${ }^{75}$ E.g., 15 U.S.C. $\S \S 2056$ c(a); 22 U.S.C. $\S ~ 5504(a) ; 25$ U.S.C. $§ 1406(b),(c)$.
} 
Some agencies, like the Internal Revenue Service ${ }^{76}$ and Federal Election Commission, ${ }^{77}$ exercise express discretion under their organic statute, commonly in the form of compliance checks or audits. Such an investigation may follow a telephone call received on a tip line, a whistleblower complaint, or some reason for the agency to suspect a violation. But even if the agency does not have a discrete reason to audit a party, it may employ a random audit ${ }^{78}$ to decrease the probability that violators can strategically evade enforcement. ${ }^{79}$ The audit might not be completely random. An agency might pay attention to particular industries or fields under its regulatory purview. ${ }^{80}$

Once the agency elects to investigate, there are a number of possible outcomes, all of which (under our definition) carry the perceived threat or actual consequence of compulsion. The agency may decide to commence an adjudication or rulemaking, although the adjudication may be the agency finding a liability yet declining to seek an immediate remedy. ${ }^{81}$ Conversely, the agency might decline to commence an adjudication or rulemaking for the time being. An outcome from an agency investigation that yields an agency action could be a compliance action. For example, a grant-distributing agency must comply with its organic statute and the Office of Management and Budget's various circulars via audits for compliance purposes. Sometimes, there is the authority to engage in an audit outside the periodic time requirement in response to allegations or suspicion of fraud or bad action.

An adjudication or rulemaking does not necessarily need to be the goal, however. An agency could investigate for the purpose of discovering and logging "informal enforcement actions." For example, the EPA maintains Enforcement and Compliance History Online, which is a searchable, publicly accessible database about corporate violations, provides data on "informal enforcement actions." 82 An agency investigation might also result in management audits, where agencies work with regulated parties to ensure that regulated parties are prepared to follow the law. Of course, to fall within our definition of "agency investigation," the interaction between the agency and the regulated parties must at some point carry at minimum the perceived threat of coercion.

So, what is not an agency civil investigation? Negative definitions are helpful because the APA does not precisely or exhaustively define all forms of agency conduct or behavior.

\footnotetext{
${ }^{76}$ Audit Techniques Guides, INTERNAL REVENUE SERV., https://www.irs.gov/businesses/smallbusinesses-self-employed/audit-techniques-guides-atgs (last visited Dec. 17, 2020) (industryspecific audit guidances).

7726 U.S.C. $\$ \S 9007(\mathrm{a}), 9008(\mathrm{~g}), 9038(\mathrm{a})$.

${ }^{78}$ Chaves Cnty. Home Health Serv., Inc. v. Sullivan, 931 F.2d 914, 916 (D.C. Cir. 1991).

79 See United States v. Biswell, 406 U.S. 311, 316 (1972); Mariano-Florentino Cuéllar, Auditing Executive Discretion, 82 NOTRE DAME L. REV. 227, 299 (2006).

${ }^{80}$ Audit Techniques Guides, supra note 76.

${ }^{81}$ See, e.g., Rhea Lana, Inc. v. Dep't of Labor, 824 F.3d 1023 (D.C. Cir. 2016).

${ }^{82}$ Enforcement and Compliance History Online, U.S. Env't Prot. Agency, https://echo.epa.gov/ (last visited Dec. 17, 2020). An example page is here: Detailed Facility Report, https://echo.epa.gov/detailed-facility-report?fid=110070032218 (last visited Dec. 17, 2020).
} 
Indeed, the APA is replete with negative definitions. ${ }^{83}$ The APA also hints at investigative functions without defining, positively or negatively, that term. ${ }^{84}$ Some courts have impliedappropriately so, in our view — at investigative acts being categorically distinct from other types of "agency action," including adjudications or rules. ${ }^{85}$

Proceedings with positive APA procedures like rulemakings or adjudications are not agency investigations; our definition does not equate to everything leading up to, or just short of, the completion of rulemakings or adjudications. For instance, we define agency investigations to exclude pre-decisional adjudicational and rulemaking processes where the decision to charge a party has been formally made and an impartial decisionmaker now has jurisdiction over the case. ${ }^{86}$ Although a neutral agency decisionmaker conducting hearings as part of the formal adjudication process is literally "investigating" a claim and assessing whether the complaint has merit, we exclude these types of proceedings because the agency is acting in a quasi-judicial role. Such proceedings feature fewer problems, as we discuss below in Part V, and objections to agency abuses committed during the adjudicatory or rulemaking process can often be raised to an impartial decisionmaker. Our definition thus requires that there be a lack of APA positive procedures, so the process of rulemaking and adjudication is not an "investigation." 87

An agency investigation could result in collateral issues during and following agency action. Instead of the agency deciding whom to pursue or whether to pursue someone, the agency could be deciding the size of a penalty. For example, the Office of Thrift Supervision may assess civil fines against a party that violates banking laws or regulations or breaches a fiduciary duty. In assessing fines, the agency, by statute, must consider mitigating factors like the size of the subpoenaed party's financial resources. ${ }^{88}$

${ }^{83}$ The APA has a negative definition of informal adjudication as adjudication that is not formal. 5 U.S.C. § 554(a); see also SecurityPoint Holdings, Inc. v. Transp. Sec. Admin., 769 F.3d 1184, $1187-88$ (D.C. Cir. 2014) (applying § 555(e) to informal adjudications). Similarly, "agency" is a general definition with a number of negative carveouts. 5 U.S.C. $\S 551(1)$.

${ }^{84}$ See, e.g., id. $\S 554(\mathrm{~d})$.

${ }^{85}$ United States v. W.H. Hodges \& Co., 533 F.2d 276, 278 (5th Cir. 1976) (per curiam); see Sierra Club v. Peterson, 185 F.3d 349, 366 n.25 (5th Cir. 1999), on reh'g, 228 F.3d 559 (5th Cir. 2000) (dicta).

${ }^{86}$ We have also structured our definition to exclude "enforcement actions." For example, in the SEC context, enforcement actions mean all the legal proceedings that the commission brings that would normatively be considered "final agency action" under the APA. Urska Velikonja, Reporting Agency Performance: Behind the SEC's Enforcement Statistics, 101 CoRNELL L. REV. 901, 903-04 (2016).

${ }^{87}$ This is because the APA provides the general contours of process for rulemaking and adjudication. See 5 U.S.C. $\S \S 553,556,557$.

${ }^{88}$ See 12 U.S.C. $§ 1818(i)(2) ;$ In re Sealed Case (Admin. Subpoena), 42 F.3d 1412, 1416 (D.C. Cir. 1994). 
Our affirmative definition covers only civil agency investigations. Criminal investigations by agencies are a separate inquiry beyond the scope of this Article. ${ }^{89}$ Additional constitutional safeguards apply if the investigation is for a criminal offense, including if a civil investigation shifts into a criminal investigation. ${ }^{90}$ That said, criminal investigations are often intertwined with civil investigations and are frequently the outgrowth of an investigation that may have begun with a purely civil aim.

Our definition excludes non-coercive action. ${ }^{91}$ While an agency investigation can be non-coercive or non-intrusive, this Article concerns only coercive or intrusive actions — or actions carrying the threat of possible future coercion, or the perception of coercion-such that the respondent would want to challenge them. Purely voluntary requests, such as civil extradition mutual legal assistance treaty information requests from foreign countries or Hague Convention requests for evidence, implicate fewer of the concerns we identify later on, and also permit a brighter line by their exclusion. We do recognize that at some point, a significant investment in non-coercive factfinding can morph into an investigation. The line can be subtle and vary among and within agencies.

Finally, our definition of investigative act excludes investigations by entities that are not "agencies." To make that determination, we look to the familiar APA definition of an "agency," which carves out Congress, the courts, state and territorial governmental entities, and so forth. ${ }^{92}$ Thus, this Article does not examine investigations by Article I actors or Article III courts. ${ }^{93}$ We also exclude certain entities from the APA definition that courts have construed as non-agencies, such as Presidential czars within the Executive Office of the President.

${ }^{89}$ Criminal investigations merit a separate investigation, but are typically associated with federal employees classified under the U.S. Office of Personnel Management's Series GS-1811. See OfFice of Personnel Mgmt., Job FAmily Position Classification Standard For AdMinistrative Work In THE JUSTICE AND NATIONAL SECURITY GROUP, 1800, at 12-14, https://www.opm.gov/policy-data-oversight/classification-qualifications/classifying-generalschedule-positions/standards/1800/1800a.pdf (last visited Dec. 17, 2020). Employees classified as 1811 investigators "supervise, lead, or perform work involving planning, conduct, or managing investigations related to alleged or suspected criminal violations of Federal laws." U.S. OfFICE PERSONNEl MANAGEMENT, HANDBOOK OF OCCUPATIONAL GROUPS AND FAMILIES 109 (Dec. 2018), https://www.opm.gov/policy-data-oversight/classificationqualifications/classifying-general-schedule-positions/occupationalhandbook.pdf.

${ }^{90}$ See generally Risa Berkower, Sliding Down A Slippery Slope? The Future Use of Administrative Subpoenas in Criminal Investigations, 73 FORDHAM L. REV. 2251 (2005). ${ }^{91}$ Cf., e.g., United States v. Bailey, 228 F.3d 341, 348 (4th Cir. 2000) (administrative subpoenas "commence[] an adversary process").

925 U.S.C. $\S 551(1)$.

${ }^{93}$ See, e.g., Matt Zapotosky, Judiciary Closes Investigation of Sexual Misconduct Allegations against Retired Judge Alex Kozinski, WASH. Post (Feb. 5, 2018), https://www.washingtonpost.com/world/national-security/judiciary-closes-investigation-ofsexual-misconduct-allegations-against-retired-judge-alex-kozinski/2018/02/05/e3a94bb8-0ac011e8-95a5-c396801049ef_story.html?utm_term=.e6d743a65704. 
In sum, an investigative act lies early on a spectrum of total agency behavior. Agency activity progresses from a triggering event to an investigation, then to the beginning of an "agency action." If the action is adjudication, then the investigation ends with the allegation of a legal violation. If the action is rulemaking, then the investigation ends with the commencement of a rulemaking process.

\section{AgenCy InVEStigative TeChNiQues And Methods}

Before understanding agency investigation norms and the appropriate legal response to agency investigations, it is necessary to understand precisely how agencies accomplish their investigations. First, agencies often can issue subpoenas to inspect documents and other physical materials. ${ }^{94}$ Some agencies issue national security letters ${ }^{95}$ or "civil investigative demands" 96 on responding parties. ${ }^{97}$ Other organic statutes endow agencies with the authority to conduct audits, by which the government gains documents or information. ${ }^{98}$ Congress has not given any agency the power to enforce such orders with contempt powers, although some state courts have permitted state agencies the power to punish disobedience with contempt. ${ }^{99}$

Second, many agencies can inspect property or enter premises, sometimes for the purpose of inspecting records. ${ }^{100}$ The organic statute does not need to explicitly authorize searches, as courts will sometimes infer an agency's ability to search. ${ }^{101}$

${ }^{94}$ See generally LAFAVE, 2 SEARCH \& SEIZURE $§ 4.13$ n.4 (5th ed.) (listing examples); see also, e.g., 7 U.S.C. § 449m (Department of Agriculture); 15 U.S.C. § 1311 (Department of Justice Antitrust Division); 18 U.S.C. $\S 923(\mathrm{~g})(1)(\mathrm{B}),(\mathrm{C})$ (Attorney General may inspect the records of certain licensed firearm importers, manufacturers, and dealers); 26 U.S.C. $\S \S 5123$ (a) (IRS), $\S 7609$ (IRS third-party summonses); 29 U.S.C. $§ 521$ (a) (Secretary of Labor); 49 U.S.C. $\S 32910(\mathrm{a})(1)(\mathrm{A})$ (Secretary of Transportation and the Administrator of the Environmental Protection Agency); 52 U.S.C. § 20703 (Attorney General may inspect and copy certain records related to federal elections); Belle Fourche Pipeline Co. v. United States, 554 F. Supp. 1350, 1359 (D. Wyo. 1983). See also U.S. Dep't of Justice, Office of LeGal Policy, Report to CONGRESS ON THE USE OF AdMINISTRATIVE SubPOENA AuthORITIES BY EXECUTIVE BRANCH AgENCIES AND ENTITIES apps. (2002), https://www.justice.gov/archive/olp/rpt_to_congress.htm\#4.

9518 U.S.C. $\S \S 2709$, 3511; see Doe v. Gonzales, 546 U.S. 1301 (2005) (Ginsburg, J., in chambers).

${ }^{96}$ Consumer Fin. Prot. Bureau v. Accrediting Council for Indep. Colls. \& Schs., 854 F.3d 683, 688 (D.C. Cir. 2017).

${ }^{97}$ See also James E. Pfander \& Daniel D. Birk, Article III Judicial Power, the Adverse-Party Requirement, and Non-Contentious Jurisdiction, 124 YALE L.J. 1346, 1379-80 (2015) (tracing a since-rejected view of Justice Field that agencies should conduct investigations without the aid of federal courts, and thus without the aid of the judiciary's subpoena power).

${ }^{98}$ Cuéllar, supra note 79, at 252-5876-82.

${ }^{99}$ HiCKMAN \& PIERCE, supra note $19, \S 8.2$.

${ }^{100}$ E.g., 15 U.S.C. $\S 2065$ (a) (Federal Trade Commission); 26 U.S.C. $§ ~ 5123(b)$ (IRS); 30 U.S.C. $\S 1267$ (a) (Department of the Interior); 42 U.S.C. $\S 7542(\mathrm{~b})(2)$ (Environmental Protection 
Third, agencies may make voluntary requests for interview or documents. ${ }^{102}$ Agencies can issue such requests against third parties, perhaps before the investigative learns that it is under investigation. In doing so, agencies can liaise with state and local agencies. ${ }^{103}$ Of course, if these requests do not carry the perceived, eventual, or actual threat of compulsion for the party under investigation, then they lie outside our definition of investigative action.

Finally, an agency may engage in noncoercive monitoring practices. These include checking databases, public or private, ${ }^{104}$ maintaining interagency lines of communication; ${ }^{105}$ setting up a tip line; ${ }^{106}$ conducting laboratory work, as with the Department of Commerce's National Institute of Standards and Technology; ${ }^{107}$ and even reading the mail from the public such as an IRS Form 13909 Tax-Exempt Organization Complaint (Referral). One source of information at an agency's disposal is tips, inspector general findings, periodic reports from grantees, audits, charges, and complaints that it may receive at low to no cost. ${ }^{108}$ Passive practices require something more than merely watching the news or parsing the internet. ${ }^{109}$ Such monitoring practices, though facially non-coercive, can carry coercive tendencies if coupled with a subjectively-inferred threat of firmer action.

Congress must authorize an agency, at least implicitly, to use these tools. The APA contemplates agencies having such power and provides an agency with power to make "process, requirement of a report, inspection, or other investigative act or demand," including a subpoena

Agency); 49 U.S.C. $\S 60120(a)(2)$ (Secretary of Transportation may request the Attorney General bring a civil action to allow for on-site inspections to enforce 49 U.S.C. $\S \S 60101-$ 60141, regarding pipeline safety).

${ }^{101}$ E.g., Blackie's House of Beef, Inc. v. Castillo, 659 F.2d 1211, 1221-22 (D.C. Cir. 1981); see Dow Chem. Co. v. United States, 476 U.S. 227, 233 (1986).

${ }^{102}$ E.g., Kerry Flynn, Why the FBI Is Investigating Media Buying Practices, DiGIDAY (Oct. 15, 2018), https://digiday.com/marketing/fbi-investigating-media-buying-practices/.

${ }^{103}$ E.g., 29 U.S.C. $§ 211$ (b) (Department of Labor may use the services of state and local labor agencies with consent); see also 27 U.S.C. $§ 202$ (f) (Department of Treasury may work with "any department or other agency of the Government" to enforce the Federal Alcohol Administration Act).

${ }^{104}$ Case Development and Limited Review Investigations, U.S. Dep't of Labor, Employee Benefits Sec. Admin., https:/www.dol.gov/agencies/ebsa/about-ebsa/ouractivities/enforcement/oe-manual/case-development-and-limited-review-investigations (last visited Dec. 17, 2020).

${ }^{105} \mathrm{Id}$.

${ }^{106}$ E.g., HSI Tip Form, U.S. IMMIGRATION \& CUSTOMS ENF’'T, https://www.ice.gov/webform/hsitip-form (last updated Aug. 23, 2018).

10715 U.S.C. $\S \S 271-281 \mathrm{a} ;$ see Davis, supra note 13, at 1114.

${ }^{108}$ E.g., 7 U.S.C. $\S 193(a) ; 8$ U.S.C. $§ 274 a(b)(1) ; 29$ U.S.C. $\S 151$ et seq.

${ }^{109}$ See Davis, supra note 13, at 1114. For more information on how agencies use internet evidence in their adjudications, see ADMINISTRATIVE CONFERENCE OF THE UNITED STATES, INTERNET EVIDENCE IN AGENCY ADJUDICATION (2019), https://www.acus.gov/researchprojects/internet-evidence-agency-adjudication. 
if "authorized by law." 110 However, the APA does not independently empower agencies to issue subpoenas or inspect property. ${ }^{111}$

Rather, the primary source of an agency's investigative authority is its organic statutes. The authority of an administrative agency to investigate is created solely by statute. ${ }^{112}$ By one count, "Congress has passed more than 300 administrative subpoena statutes grant[ing] some form of administrative subpoena authority to most federal agencies." "113 But creating some tension with that fundament, the Supreme Court held in Dow Chemical Co. v. United States that "[r] egulatory or enforcement authority generally carries with it all the modes of inquiry and investigation traditionally employed or useful to execute the authority granted."114 Dow Chemical does not require an agency endowed with investigatory or enforcement authority "to identify explicitly each and every technique that may be used in the course of executing the statutory mission." "115 Courts have used this language-sometimes alongside an organic statute's legislative history ${ }^{116}$ _ to permit certain modes of investigatory inspection or searches that are not specifically authorized by statute. ${ }^{117}$

Expansive readings of this sort are sometimes necessary, as organic statutes often impose no textual constraints on the investigative techniques they may use. For example, Congress has permitted the Department of Labor's Wage and Hour Division Administrator to broadly "investigate such facts, conditions, practices, or matters as he may deem necessary or appropriate to determine whether any person has violated any provision of those chapter, or which may aid

1105 U.S.C. $\S 555(\mathrm{c}),(\mathrm{d})$.

111 Attorney General's Manual on the Administrative Procedure Act 67 (1947) (“It should be emphasized that [this] relates only to an existing subpoena power conferred upon agencies; it does not grant power to issue subpoenas to agencies which are not so empowered by other statutes."); United States v. Sec. State Bank \& Trust, 473 F.2d 638, 642 (5th Cir. 1973).

112 Peters v. United States, 853 F.2d 692, 696 (9th Cir. 1988) (citing 3 B. MEZINES, J. STEIN \& J. GrufF, AdMINISTRATIVE LAW § 20.02 (1988)); Univ. of Richmond v. Bell, 543 F. Supp. 321, 332 (E.D. Va. 1982) ("[N]o inherent investigatory authority exists in a government agency but only such authority as is granted by statute.”); Consumer Fin. Prot. Bureau v. Accrediting Council for Indep. Colls. \& Schs., 854 F.3d 683, 690 (D.C. Cir. 2017) (“An administrative agency's authority to issue subpoenas 'is created solely by statute."').

${ }^{113}$ Robert A. Mikos, Can the States Keep Secrets from the Federal Government?, 161 U. PA. L. REV. 103, 117 (2012) (alteration in original) (internal quotation marks omitted); see Subpoena Authority, Stanford UniV. \& Administrative CONFERENCE of THE United STATES, https://acus.law.stanford.edu/reports/subpoena (last visited Dec. 17, 2020).

${ }^{114}$ Dow Chem. Co. v. United States, 476 U.S. 227, 233 (1986).

${ }^{115} I d$..

116 See, e.g., Boliden Metech, Inc. v. United States, 695 F. Supp. 77, 81 (D.R.I. 1988) (citing Toxic Substances Control Act, Conf. Rep. S. 3149, 94th Cong., 2d Session, reprinted in 1976 U.S. Code Cong. and Admin. News 4491, 4572-73).

${ }^{117}$ Nat'l-Standard Co. v. Adamkus, 881 F.2d 352, 362 (7th Cir. 1989) (background sampling, although not specified in statute, was permissible under 42 U.S.C. $\S 6927(a)$ ). 
in the enforcement of the provisions of this chapter." 118 Similar expansive authority is held by the Office of Foreign Asset Control, ${ }^{119}$ the Drug Enforcement Administration, ${ }^{120}$ and the U.S. Postal Service. ${ }^{121}$ These textually broad delegations of investigatory authority provide little constraint to agencies' exercise of discretion in utilizing investigatory tools.

\section{CONSTRAINTS ON AgENCY INVESTIGATIONS}

There are several legal levers that check overzealous exercises of agency investigative authority with varying degrees of success. They include tools under the U.S. Constitution, Administrative Procedure Act and other applicable statutes and regulations. These legal levers tend to sort into a binary hard versus soft paradigm. "Hard" checks are constraints on investigative acts that can be applied more directly by parties aggrieved by investigative acts, such as Fourth Amendment challenges to the relevancy of an agency investigative act. "Soft" checks are constraints that include the articles of the U.S. Constitution embodying the doctrine of the separation of powers, congressional oversight, public pressure, executive or agency selfconstraint, and agency culture.

\section{A. Constitutional Constraints}

\section{i. Constitutional Civil Liberties}

The Founders did not contemplate the modern administrative state and the complex civil society that it regulates. ${ }^{122}$ The administrative state, which has grown rapidly since the New Deal era, "has seemingly become an irresistible force" which "has collided with what at first were apparently immovable constitutional principles concerning privacy, searches and seizures, self-incrimination, and freedom from bureaucratic snooping." 123 In the wake of that era, courts have held repeatedly that the Constitution permits an agency to exercise investigative functions. ${ }^{124}$

Nevertheless, the Constitution's protections of civil liberties can serve to limit meandering agency investigations. The primary guarantee of personal rights against improper investigations is the Fourth Amendment. The Supreme Court has not interpreted these protections to be robust in the civil setting. Generally, the agency's power of access "is more analogous to the Grand Jury, which does not depend on a case or controversy for power to get

\footnotetext{
11829 U.S.C. $\S \S 211$ (a) (Fair Labor Standards Act), 2616(a) (for Family and Medical Leave, same).

11950 U.S.C. $\S 1702(\mathrm{a})(1)-(2)$.

12021 U.S.C. $\$ \S 882(\mathrm{f}), 880,965$; see 21 C.F.R. $\$ 1316.03$.

12139 U.S.C. $\S 404(\mathrm{a})(6)$; see 39 C.F.R. $\S 233.1$.

${ }^{122}$ Gary Lawson, The Rise and Rise of the Administrative State, 107 HARV. L. REV. 1231, 1233 (1994).

${ }^{123}$ Davis, supra note 13.

${ }^{124}$ See, e.g., FTC v. Cinderella Career \& Finishing Schs., Inc., 404 F.2d 1308, 1315 (D.C. Cir. 1968) (collecting cases); In re McVane, 44 F.3d 1127, 1134 (2d Cir. 1995) ("Courts have imposed few constitutional limitations on agencies' power to issue administrative subpoenas.”).
} 
evidence, but can investigate merely on suspicion that the law is being violated, or even just because it wants assurance that it is not." 125

The Fourth Amendment interacts differently with certain types of agency investigatory tools. Starting with subpoenas, an agency subpoena, including to appear at a deposition, ${ }^{126}$ conducts a "constructive search." 127 The Fourth Amendment erects a number of hurdles on such subpoenas, albeit of varying heights. In the modern Fourth Amendment jurisprudential landscape, as first annunciated in United States v. Morton Salt Co. and Oklahoma Press Publishing Co. v. Walling, ${ }^{128}$ a party may launch a "strictly limited" challenge to an agency's subpoena in enforcement proceedings. ${ }^{129}$ The moving party must demonstrate that the agency has failed any of four showings that favor the agency.

${ }^{125}$ United States v. Morton Salt Co., 338 U.S. 632, 642-43 (1950).

12616 C.F.R. $\S 3.33$ (FTC permits depositions); Amendments to the Commission's Rules of Practice, 80 Fed. Reg. 60,091 (Oct. 5, 2015) (SEC proposing to allow depositions).

${ }^{127}$ Okla. Press Pub'g Co. v. Walling, 327 U.S. 186, 202 (1946); cf. McLane Co. v. EEOC, 137 S. Ct. 1159, 1169 (2017) (appearing to distance subpoena-quashing jurisprudence from the Fourth Amendment by stating that Oklahoma Press "implied that the Fourth Amendment is the source of the requirement that subpoena not be "too indefinite").

${ }^{128}$ Morton Salt Co., 338 U.S. at 652; Okla. Press Pub'g Co., 327 U.S. at 209; see also United States v. Stuart, 489 U.S. 353, 359 (1989) (in a more modern case, enforcing this requirement). ${ }^{129}$ FTC v. Texaco, Inc., 555 F.2d at 871-72; Univ. of Medicine \& Dentistry of N.J. v. Corrigan, 347 F.3d 57, 64 (3d Cir. 2003); accord Equal Emp't Opportunity Comm'n v. Bay Shipbuilding Corp., 668 F.2d 304, 330-31 (7th Cir. 1981) (calling administrative subpoena enforcement proceedings "of a summary nature not requiring the issuance of process, hearing, findings of fact, and the elaborate process of a civil suit" (quoting Goodyear Tire \& Rubber Co. v. Nat'l Labor Relations Bd., 122 F.2d 450, 451 (7th Cir. 1941))). 
The following chart summarizes the dimensions of these standards that we discuss, below, follows:

\begin{tabular}{|c|c|}
\hline \multicolumn{2}{|c|}{$\begin{array}{l}\text { Fourth Amendment Showings Necessary to Challenge } \\
\text { Pre-Adjudication Civil Investigatory Agency Subpoena }\end{array}$} \\
\hline Standard & Requirements on Agency \\
\hline $\begin{array}{l}\text { Is the subpoena in the } \\
\text { agency's authority? }\end{array}$ & 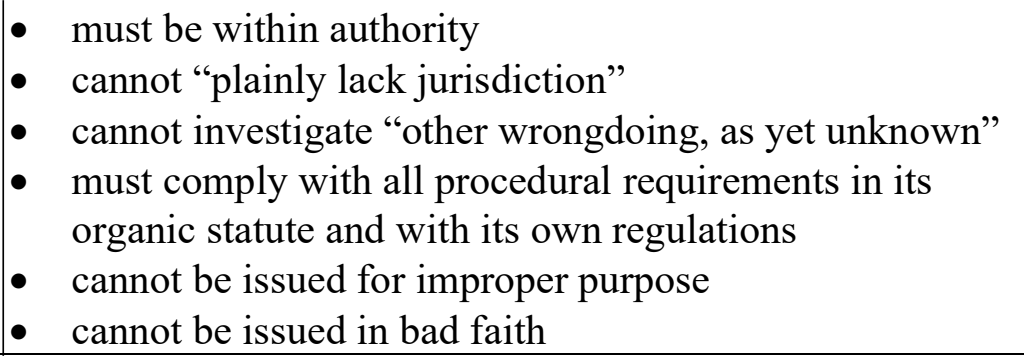 \\
\hline $\begin{array}{l}\text { Is the subpoena "reasonably } \\
\text { relevant"? }\end{array}$ & $\begin{array}{l}\text { - agency's own appraisal of relevancy, which "must be } \\
\text { accepted so long as it is not obviously wrong" } \\
\text { may hinge on whether the target of investigation is a } \\
\text { person or a business association }\end{array}$ \\
\hline $\begin{array}{l}\text { Is the subpoena overbroad or } \\
\text { improper in scope? }\end{array}$ & $\begin{array}{l}\text { - } \begin{array}{l}\text { cannot be "too indefinite" } \\
\text { - cannot be "unreasonably broad" } \\
\text { must be "sufficiently limited in scope," subject to federal } \\
\text { privilege law }\end{array} \\
\end{array}$ \\
\hline $\begin{array}{l}\text { Is the subpoena unduly } \\
\text { burdensome? }\end{array}$ & - cannot unduly burden the respondent \\
\hline
\end{tabular}

First, an agency subpoena must be within the agency's authority to issue. ${ }^{130}$ This requirement is variously articulated as whether the agency "plainly lacks" jurisdiction. ${ }^{131}$ That is, an agency cannot simply serve a subpoena seeking information to investigate "other wrongdoing, as yet unknown."132 Relatedly, an agency must comply with all procedural requirements in its organic statute and with its own regulations, ${ }^{133}$ for example, if the statute requires the agency to state the nature of its investigation and the law supposedly being violated. ${ }^{134}$ An agency's authority must extend not only to the type of investigatory tool used, but also to the type of information sought. For example, an agency that holds the statutory

${ }^{130}$ United States v. Powell, 379 U.S. 48 (1964); Morton Salt Co., 338 U.S. at 652; Okla. Press Pub'g Co., 327 U.S. at 209; see also United States v. Stuart, 489 U.S. 353, 359 (1989) (in a more modern case, enforcing this requirement).

${ }^{131}$ NLRB v. Chapa de Indian Health Program, Inc., 316 F.3d 995 (9th Cir. 2003).

132 In re Sealed Case (Admin. Subpoena), 42 F.3d 1412, 1419 (D.C. Cir. 1994).

${ }^{133}$ See United States ex rel. Accardi v. Shaughnessy, 347 U.S. 260 (1954).

${ }^{134}$ E.g., Consumer Fin. Prot. Bureau v. Accrediting Council for Indep. Colls. \& Schs., 854 F.3d 683, 690 (D.C. Cir. 2017). 
authority only to subpoena information to determine liability cannot enforce a subpoena of personal financial information for the purpose of assessing the individual's net worth to determine the cost-effectiveness of an investigation. ${ }^{135}$ This standard is rather lax. One circuit holds that "[a]s long as the agency's assertion of authority is not apocryphal, a procedurally sound subpoena must be enforced."136 The Supreme Court has confirmed that the assertion of authority is jurisdictional in nature, and that the familiar Chevron ${ }^{137}$ deference is due to an agency's determination of its jurisdiction. ${ }^{138}$

Relatedly, the subpoena cannot be used for an improper purpose or in bad faith. ${ }^{139}$ "Bad faith" must be institutionalized bad faith—bad faith by individual agency actors is insufficient. ${ }^{140}$ An example of "bad faith" could include "harassment of the recipient of the subpoena, or a conscious attempt by the agency to pressure the recipient to settle a collateral dispute."141 However, it is worth noting that the "purpose" of the subpoena in the seminal case establishing this requirement, United States v. Powell, was important because the agency at issue, the IRS, could issue summons for only limited purposes. ${ }^{142}$ Thus, the "improper purpose" requirement might not be available to parties challenging every type of investigative act under every type of organic statute.

${ }^{135}$ Resolution Tr. Corp. v. Walde, 18 F.3d 943, 947-49 (D.C. Cir. 1994); see Katherine Scherb, Administrative Subpoenas for Private Financial Records: What Protection for Privacy Does the Fourth Amendment Afford?, 1996 WIS. L. REV. 1075, 1085-97 (summarizing case law). Note that the D.C. Circuit does not view this ultra vires inquiry as being constitutional. Id. at 949.

${ }^{136}$ United States v. Sturm, Roger \& Co., 84 F.3d 1, 5-6 (1st Cir. 1996).

${ }^{137}$ Chevron U.S.A., Inc. v. Nat. Res. Def. Council, Inc., 467 U.S. 837 (1984).

${ }^{138}$ City of Arlington v. FCC, 569 U.S. 290 (2013). ATTORNEY GENERAL's MANUAL ON THE Administrative Procedure ACT, supra note 111, at 69 (citing Endicott Johnson Corp. v. Perkins, 317 U.S. 501 (1943); Okla. Press Pub'g Co. v. Walling, 327 U.S. 186 (1946); "Nothing the language of section 6(c) suggests any purpose to change this established rule."). The Attorney General's Manual cited the fact that an earlier APA bill specifically entitled courts to "determine all relevant questions of law raised by the parties, including the authority or jurisdiction of the agency." Id. However, that language did not make it into the enacted bill. Id. Note that the Constitution, if not the APA, allows courts to hear certain challenges to an agency's jurisdiction, per post-1946 case law from the Supreme Court.

${ }^{139}$ United States v. Powell, 379 U.S. 48, 58 (1964); Resolution Tr. Corp. v. Frates, 61 F.3d 962, 965 (D.C. Cir. 1995); see Consumer Fin. Prot. Bureau v. Accrediting Council for Indep. Colls. \& Schs., 854 F.3d 683, 689 (D.C. Cir. 2017).

${ }^{140}$ United States v. LaSalle Nat'l Bank, 437 U.S. 298, 317-18 (1978); SEC v. Wheeling-

Pittsburgh Steel Corp., 648 F.2d 118, 125 (3d Cir. 1981) (en banc); United States v. Markwood, 48 F.3d 969, 978 (6th Cir. 1995).

${ }^{141}$ United States v. Markwood, 48 F.3d 969, 978 (6th Cir. 1995).

142 Powell, 379 U.S. at 49-51, 57-58. 
Second, the subpoena must be "reasonably relevant."143 This standard appears lax, too. Because the "standard for judging relevancy in an investigatory proceeding is more relaxed than in an adjudicatory one," 144 the court "defer[s] to the agency's appraisal of relevancy, which 'must be accepted so long as it is not obviously wrong." 145 The burden of showing irrelevance lies with the responding party. ${ }^{146}$

The relevance test may hinge on whether the target of investigation is a person or a business association. This distinction derives from the penumbraic right to privacy recognized from, inter alia, the Fifth and Fourteenth Amendments, and from a statement in Morton Salt that corporations "can claim no equality with individuals in the enjoyment of a right to privacy." 147 This test is consistent with the APA's House Judiciary Committee Report, which opined that an agency "investigation must be substantially and demonstrably necessary to agency

operations." 148 The effect of this distinction may be a lower bar for the responding party to show irrelevance, ${ }^{149}$ especially if the responding party is a third party who is not the target of the agency's investigation. ${ }^{150}$

Third, the subpoena must not be "too indefinite"151 or "unreasonably broad,"152 and it must be "sufficiently limited in scope."153 Federal privilege law governs the subpoena's scope. ${ }^{154}$

${ }^{143}$ Powell, 379 U.S. 48; United States v. Morton Salt Co., 338 U.S. 632, 652 (1950); Okla. Press Pub'g Co. v. Walling, 327 U.S. 186, 209 (1946); see also United States v. Stuart, 489 U.S. 353, 359 (1989) (in a more modern case, enforcing this requirement).

${ }^{144}$ Fed. Trade Comm'n v. Invention Submission Corp., 965 F.2d 1089, 1090 (D.C. Cir. 1992).

${ }^{145}$ Resolution Tr. Corp. v. Walde, 18 F.3d 943, 946 (D.C. Cir. 1994).

${ }^{146}$ Fed. Trade Comm'n v. Invention Submission Corp., 965 F.2d at 1090.

147338 U.S. at 652.

${ }^{148}$ H. Rep. 1980 at 264 (May 3, 1946).

${ }^{149}$ In re McVane, 44 F.3d 1127, 1137 (2d Cir. 1995); United States v. Harrington, 388 F.2d 520, 524 (2d Cir. 1968); cf. Doe v. United States, 253 F.3d 256, 270 (6th Cir. 2002); FDIC v. Garner, 126 F.3d 1138, 1143-44 (9th Cir. 1997).

${ }^{150}$ In re McVane, 44 F.3d at 1137-38.

${ }^{151}$ United States v. Powell, 379 U.S. 48 (1964); Morton Salt Co., 338 U.S. at 652; Okla. Press Pub'g Co. v. Walling, 327 U.S. 186, 209 (1946); see also United States v. Stuart, 489 U.S. 353, 359 (1989) (in a more modern case, enforcing this requirement).

${ }^{152}$ See, e.g., FTC v. Texaco, Inc., 555 F.2d at 881-82; N.L.R.B. v. Am. Med. Response, Inc., 438 F.3d 188, 192 (2d Cir. 2006).

${ }^{153}$ See v. City of Seattle, 387 U.S. 541, 544 (1967).

154 See, e.g., Linde Thomson Langworthy Kohn \& Van Dyke, P.C. v. Resolution Tr. Corp., 5 F.3d 1508, 1513 (D.C. Cir. 1993) (citing FTC v. TRW, Inc., 628 F.2d 207, 210-11 (D.C. Cir. 1980) (FTC); Dole v. Milonas, 889 F.2d 885, 889 n.6 (9th Cir. 1989) (ERISA); United States v. Schoenheinz, 548 F.2d 1389, 1390 (9th Cir. 1977) (IRS); Colton v. United States, 306 F.2d 633, 636 (2d Cir. 1962) (IRS)). 
Fourth, the subpoena cannot be "unduly burdensome."155 Once challenged, the burden is on the agency to show that the subpoena does not impose undue burdens. ${ }^{156}$ There are very few cases in which a court has quashed a subpoena on this basis. ${ }^{157}$

These showings are not needed until the subpoena is challenged in court; a judicial warrant is not a condition precedent to a valid administrative subpoena. ${ }^{158}$ To serve a subpoena in the first place, an agency does not need probable cause ${ }^{159}$ or reasonable suspicion. ${ }^{160}$ The agency need only be "reasonable," which means compliance with the above criteria. ${ }^{161}$ Nor must the agency "make a preliminary finding of liability before it can even initiate an investigation." "162 One possible exception is that in the D.C. Circuit at least, an agency must demonstrate an "articulable suspicion" of liability to enforce a subpoena for personal financial information. ${ }^{163}$ The fact that probable cause in the criminal sense is not required provides another incentive for agency investigators to start building their case with civil investigative tools over criminal investigative tools.

Judicial review of agency subpoenas to determine compliance with the above criteria is "strictly limited" on account of "the important governmental interest in the expeditious investigation of possible unlawful activity." 164 Courts "generally defer to an agency's interpretation of the scope of its own investigation." 165 During the proceedings to quash, a court

${ }^{155}$ See v. City of Seattle, 387 U.S. 541, 544 (1967); FCC v. Texaco, Inc., 555 F.2d 862, 882 \& n.51 (D.C. Cir. 1977); FTC v. Church \& Dwight Co., 665 F.3d 1312, 1316 (D.C. Cir. 2011). ${ }^{156}$ EEOC v. Md. Cup Corp., 785 F.2d 471, 476 (4th Cir. 1986); EEOC v. Children's Hosp. Med. Ctr., 719 F.2d 1426, 1428 (9th Cir. 1983) (en banc). Cf. FTC v. Jim Walter Corp. 651 F.2d 251, 258 (5th Cir. 1981) (putting the burden on the affected party to show that compliance would impose an unreasonable burden), abrogated on other grounds by Republic of Panama v. BCCI Holdings (Lux.) S.A., 119 F.3d 935 (11 th Cir. 1997).

${ }^{157}$ EEOC v. Aon Consulting, Inc., 149 F. Supp. 2d 601, 603 (S.D. Ind. 2001) (subpoena unduly burdensome, but conditioning enforcement on agency's willingness to enter a confidentially agreement).

${ }^{158}$ Donovan v. Lone Steer, Inc., 464 U.S. 408, 415 (1984).

${ }^{159}$ Marshall v. Barlow's, Inc., 436 U.S. 307, 320-21 (1978); accord Camara v. Municipal Court of S.F., 387 U.S. 523, 538 (1967); Okla. Press Pub'g Co. v. Walling, 327 U.S. 186, 209 (1946).

${ }^{160}$ DeMasters v. Arend, 313 F.2d 88 (1963); United States v. Morton Salt Co., 338 U.S. 632, 642-43 (1950).

161 United States v. Powell, 379 U.S. 48, 51 (1964).

162 In re Sealed Case (Admin. Subpoena), 42 F.3d 1412, 1416 (D.C. Cir. 1994) (citing FTC v. Texaco, Inc., 555 F.2d 862, 874 (D.C. Cir. 1977)).

${ }^{163}$ Resolution Tr. Corp. v. Walde, 18 F.3d 943, 949 (D.C. Cir. 1994). The "articulable suspicion" requirement also applies to determining an individual's ability to pay a civil penalty. In re Sealed Case (Admin. Subpoena), 42 F.3d 1412, 1417 (D.C. Cir. 1994).

${ }^{164}$ U.S. Int'1 Trade Comm'n v. ASAT, Inc., 411 F.3d 245, 253 (D.C. Cir. 2005) (quoting FTC v. Texaco, Inc., 555 F.2d at 872).

${ }^{165}$ Consumer Fin. Prot. Bureau v. Accrediting Council for Indep. Colls. \& Schs., 854 F.3d 683, 689 (D.C. Cir. 2017) (citing FTC v. Church \& Dwight Co., 665 F.3d 1312, 1315-16 (D.C. Cir. 
will not hear substantive defenses that the investigated party may have to the underlying investigation during its pendency. ${ }^{166}$ Arguments that the respondent is not within the agency's jurisdiction may typically only be made in defense of an administratively exhausted final enforcement action. ${ }^{167}$ Another nigh insurmountable challenge is that an investigated party might not know that an administrative subpoena went out to a third party, or might not have standing to challenge the demand. ${ }^{168}$

If the movant succeeds in enforcement proceedings, the remedy is unclear. Courts sometimes imply that the agency need only reissue the problematic subpoena within certain parameters ${ }^{169}$ and sometimes suggest they are executable as modified by the court. ${ }^{170}$ Regardless of the procedure the agency must undertake going forward, it is not difficult or burdensome for the agency to quickly demand from a party the maximum amount of information that it is allowed. Even when the subpoena is quashed, the remedy is often "limited to a judicial requirement that the agency narrow the scope of the subpoena or identify the materials sought with greater specificity." 171

Yet courts will, rarely, vindicate the right not to be investigated beyond statutory authority once the investigation and then final agency action has concluded. One circuit court held that the agency's “comprehensive initial investigation ... pursuant to the Secretary's standard practice exceeded his statutory authority from the outset." ${ }^{172}$ In fashioning a remedy, that court simply struck the administrative findings of violations and awards against the investigated party. ${ }^{173}$

The following chart summarizes the domain of administrative subpoenas before and after the Supreme Court's decisions in Oklahoma Press Publishing Co. and Morton Salt Co. The chart compares these standards with the standards for grand jury subpoenas, another type of

2011); Dir., Office of Thrift Supervision v. Vinson \& Elkins, LLP, 124 F.3d 1304, 1307 (D.C. Cir. 1997)).

${ }^{166}$ FTC v. Texaco, Inc., 555 F.2d at 879.

${ }^{167}$ McLane Co. v. EEOC, 137 S. Ct. 1159, 1165 (2017); CSG Workforce Partners, LLC v. Watson, 512 F. App'x 830, 836 (10th Cir. 2013); Donovan v. Shaw, 668 F.2d 985, 989 (8th Cir. 1982); FTC v. Ken Roberts Co., 276 F.3d 538, 584 (D.C. Cir. 2001); FMC v. Port of Seattle, 521 F.2d 431 (9th Cir. 1975); SEC v. Savage, 513 F.2d 188 (7th Cir. 1975).

${ }_{168}$ Berkower, supra note 90, at 2275-76.

${ }^{169}$ Equal Employment Opportunity Comm'n v. TriCore Reference Labs., 849 F.3d 929, 943 (10th Cir. 2017) (“Our decision [quashing the EEOC's subpoena] should not preclude the EEOC from formulating a request for information to overcome the concerns discussed in this opinion.”); see In re McVane, 44 F.3d 1127, 1137 (2d Cir. 1995) (implying same).

${ }^{170}$ EEOC v. Aon Consulting, Inc., 149 F. Supp. 2d 601, 603 (S.D. Ind. 2001) (permitting enforcement as modified by the court); EEOC v. United Air Lines, Inc., 287 F.3d 643, 653 (7th Cir. 2002) (implying such).

${ }^{171}$ HiCKMAN \& PIERCE, supra note 19, § 8.2 (citing United States v. Theodore, 479 F.2d 749 (4th Cir. 1973)); cf. In re Grand Jury Proceedings, 601 F.2d 162, 166 (5th Cir. 1979) (grand jury).

172 Greater Mo. Med. Pro Care Providers, Inc. v. Perez, 812 F.3d 1132, 1139 (8th Cir. 2015). ${ }^{173} \mathrm{Id}$. 
investigative subpoena, albeit one used for a criminal investigative purpose.

\begin{tabular}{|c|c|c|c|}
\hline \multicolumn{4}{|c|}{$\begin{array}{c}\text { Comparison of Procedural Protections for Administrative Subpoenas Before and After Oklahoma Press } \\
\text { Publishing Co. (1946) and Morton Salt Co. (1950), with Grand Jury Subpoenas }\end{array}$} \\
\hline Issue & $\begin{array}{l}\text { Admin. Investigation } \\
\text { before } 1950^{174}\end{array}$ & $\begin{array}{l}\text { Admin. Investigations } \\
\text { after } 1950\end{array}$ & Grand Jury Subpoena \\
\hline $\begin{array}{l}\text { Pre-issuance role of } \\
\text { Article III judge? }\end{array}$ & No & No & $\begin{array}{l}\text { Yes; convened under } \\
\text { auspices of judge }\end{array}$ \\
\hline Standard for issuance? & $\begin{array}{l}\text { Indeterminate; } \\
\text { potentially requiring } \\
\text { probable cause }\end{array}$ & $\begin{array}{l}\text { Whether agency } \\
\text { "plainly lacks" } \\
\text { jurisdiction }\end{array}$ & $\begin{array}{l}\text { Discretionary; "as it } \\
\text { considers } \\
\text { appropriate"175 }\end{array}$ \\
\hline Relevance? & $\begin{array}{l}\text { Limited to cases } \\
\text { "where the } \\
\text { investigations concern } \\
\text { a specific breach of the } \\
\text { law" }\end{array}$ & $\begin{array}{l}\text { Must be "reasonably } \\
\text { relevant" }\end{array}$ & $\begin{array}{l}\text { Must be a reasonable } \\
\text { possibility that category } \\
\text { of materials } \\
\text { Government seeks will } \\
\text { produce information } \\
\text { relevant to general } \\
\text { subject of } \\
\text { investigation }\end{array}$ \\
\hline Breadth? & $\begin{array}{l}\text { No roving "fishing } \\
\text { expeditions;" must } \\
\text { specify a reasonable } \\
\text { period of time and } \\
\text { reasonably particular } \\
\text { subjects }\end{array}$ & $\begin{array}{l}\text { Cannot be "too } \\
\text { indefinite" }\end{array}$ & $\begin{array}{l}\text { Limited by function } \\
\text { toward the possible } \\
\text { return of an } \\
\text { indictment }^{177}\end{array}$ \\
\hline $\begin{array}{l}\text { Unduly burdensome } \\
\text { standard? }\end{array}$ & Yes & Yes & $\begin{array}{l}\text { No; reasonableness and } \\
\text { oppressiveness } \\
\text { standard }^{178}\end{array}$ \\
\hline $\begin{array}{l}\text { Bad faith basis } \\
\text { acceptable? }\end{array}$ & Not explicitly & No & No \\
\hline Timing of challenge & $\begin{array}{l}\text { Apparently post- } \\
\text { issuance }\end{array}$ & $\begin{array}{l}\text { While a subpoena may } \\
\text { be challenged before } \\
\text { final agency action, the } \\
\text { investigation itself } \\
\text { otherwise may typically } \\
\text { only be made after final } \\
\text { action; no meaningful } \\
\text { judicial pre- } \\
\text { determination. }\end{array}$ & $\begin{array}{l}\text { Post-issuance as to the } \\
\text { subpoena, }{ }^{179} \text { however, } \\
\text { grand juries cannot } \\
\text { "engage in arbitrary } \\
\text { fishing expeditions, nor } \\
\text { may they select targets } \\
\text { of investigation out of } \\
\text { malice or an intent to } \\
\text { harass." } 180\end{array}$ \\
\hline
\end{tabular}

${ }^{174}$ Harriman v. ICC, 211 U.S. 407 (1908); FTC v. Am. Tobacco Co., 264 U.S. 298 (1924);

Brown v. United States, 276 U.S. 134 (1928); Jones v. SEC, 298 U.S. 1 (1936).

${ }^{175}$ United States v. Calandra, 414 U.S. 338, 343 (1974).

176 U.S. v. R. Enterprises, Inc., 498 U.S. 292, 301 (1991).

${ }^{177}$ Costello v. United States, 350 U.S. 359, 362 (1956).

178 FED. R. CRIM. P. 17(c)(2).

${ }^{179} \mathrm{Id}$.

${ }^{180}$ United States v. R. Enters., Inc., 498 U.S. 292, 299 (1991). 
We shift to administrative search warrants, which are less difficult to challenge than an administrative subpoena. A warrant is generally required before an agency may conduct a "search" within the Fourth Amendment. ${ }^{181}$ The Supreme Court has recognized exceptions for a motley assortment of certain regulated industries: those involving liquor, ${ }^{182}$ firearms, ${ }^{183}$ mining, ${ }^{184}$ or junkyards ${ }^{185}$ _ but not hotel operation ${ }^{186}$ or commercial activity generally. ${ }^{187}$

To validly execute an administrative warrant, an agency must provide a court with discrete evidence of an existing violation, ${ }^{188}$ or a "reasonable belief" or "reasonable suspicion." 189 The search must be part of a general neutral administrative plan. ${ }^{190}$ An agency may not conduct an investigation outside the scope of its authority, although probable cause in the criminal sense is not required. ${ }^{191}$

We reiterate that the landscape is different in the criminal context (although that lies beyond the scope of this Article). Also, "evidence implicating diminished privacy interests or for a corporation's own books" might not be protected by the Fourth Amendment. ${ }^{192}$

Another amendment of the Bill of Rights that protects subjects of agency investigations is the Fifth Amendment's Self-Incrimination Clause. Regarding revealing document contents, this Clause protects the respondent only from compelled self-incrimination. ${ }^{193}$ This hinges on how the documents were originally prepared; if the responding party prepared business records voluntarily, even if before the investigation, then the compulsion is constitutional. ${ }^{194}$

Under the same reasoning, regarding the act of document production, the SelfIncrimination Clause may be invoked only when the subpoena or warrant "compels the holder of the document to perform an act that may have testimonial aspects and an incriminating effect."195 Those aspects may be present, for example, if "[c]ompliance with the subpoena tacitly concedes

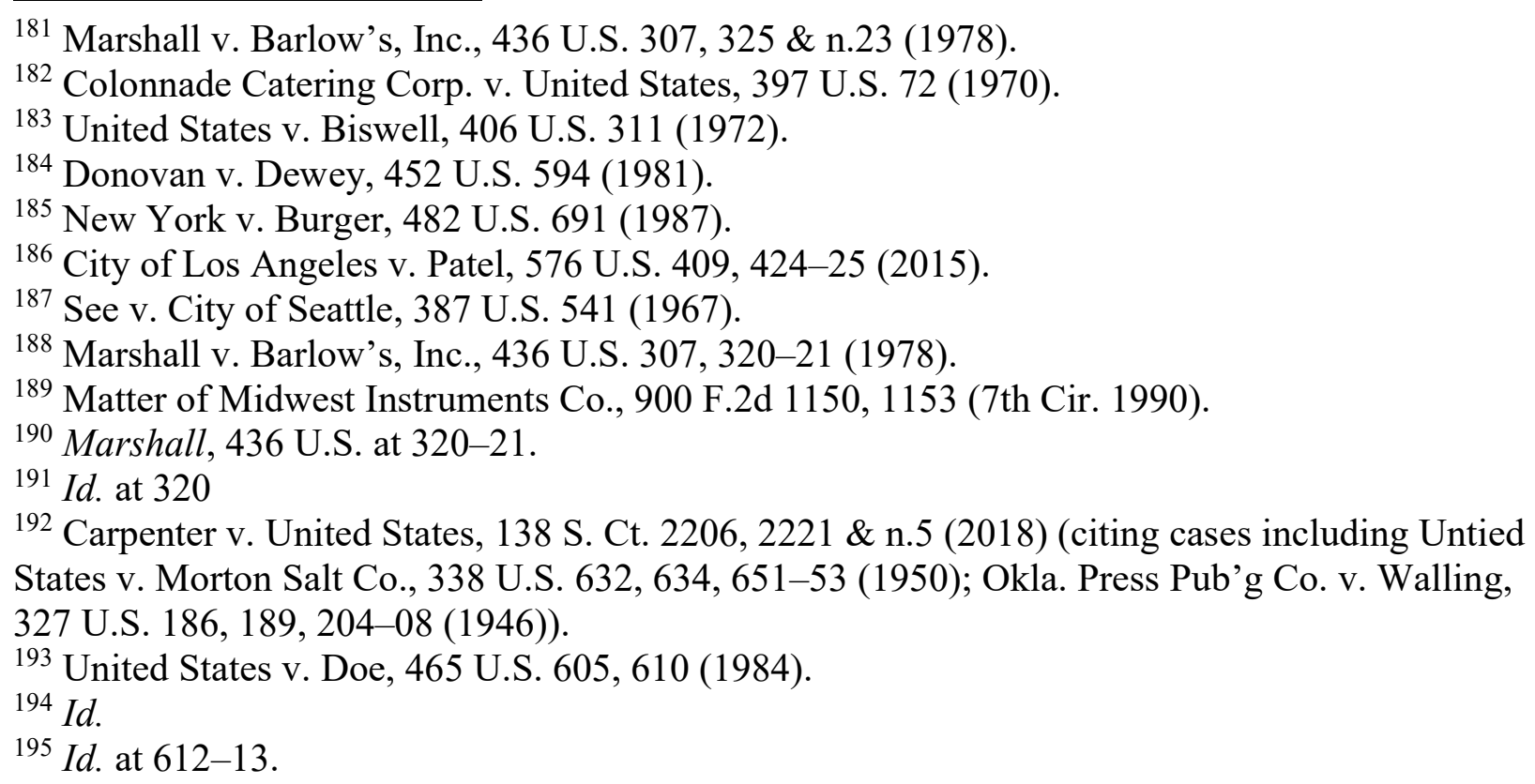


the existence of the papers demanded." ${ }^{196}$ But where a respondent is required to comply with a regulatory regime unrelated to criminal law enforcement - as is often the case with regulated industries - there is no Self-Incrimination Clause privilege available. ${ }^{197}$

Moreover, the Self-Incrimination Clause is inapplicable with regard to third-party subpoenas. ${ }^{198}$ The Self-Incrimination Clause may, however, be invoked in an agency investigation to protect against a disclosure that the respondent reasonably believes could be used against it in a criminal proceeding or could lead to other such evidence. ${ }^{199}$

The Supreme Court interprets the Fifth Amendment's Due Process Clause to provide even less protection against improper agency investigations. ${ }^{200}$ Writing for the Court in 1960, Chief Justice Warren acknowledged that due process "is an elusive concept," but that "when governmental action does not partake of an adjudication, as for example, when a general factfinding investigation is being conducted, it is not necessary that the full panoply of judicial procedures be used." 201 The Due Process Clause tolerates an agency using its subpoena power to gather evidence adverse to a person under investigation without notifying him or her, as "an administrative investigation adjudicates no legal rights." 202 Similarly, the right of crossexamination generally does not apply in agency investigations. ${ }^{203}$

The Due Process Clause will also permit an agency working on an initially civil investigation that results only in a criminal prosecution. ${ }^{204}$ As the Supreme Court has held, "[t]he discovery of evidence of crimes in the course of an otherwise proper administrative

${ }^{196} I d$. at 613 (quoting United States v. Fisher, 425 U.S. 391, 410 (1976)); United States v. Hubbell, 530 U.S. 27, 43-45 (2000); see also In re Twelve Grand Jury Subpoenas, 908 F.3d 525, 528 (9th Cir. 2018).

${ }^{197}$ Shapiro v. United States, 335 U.S. 1, 17-18 (1948) (introducing the required records doctrine that is an exception to the Fifth Amendment); Balt. City Dep't of Soc. Servs. v. Bouknight, 493 U.S. 549, 555-60 (1990).

${ }^{198}$ U.S. CONST. amend. V; SEC v. Jerry T. O’Brien, Inc., 467 U.S. 735, 742 (1984) ("The rationale of this doctrine is that the Constitution proscribes only compelled self-incrimination, and, whatever may be the pressures exerted upon the person to whom a subpoena is directed, the subpoena surely does not 'compel' anyone else to be a witness against himself.") (internal citations omitted).

${ }^{199}$ Kastigar v. United States, 406 U.S. 441, 444-45 (1972).

${ }^{200}$ U.S. CONST. amend. V.

${ }^{201}$ Hannah v. Larche, 363 U.S. 420, 442 (1960).

202 Jerry T. O'Brien, Inc., 467 U.S. at 742 (internal citations omitted).

${ }^{203}$ Hannah, 363 U.S. at 445-46.

${ }^{204}$ Doe v. United States, 253 F.3d 256, 265 (6th Cir. 2001) ("Both the Supreme Court and this circuit have long applied [the reasonableness] test when reviewing administrative subpoena requests, and we see no convincing basis upon which to distinguish these binding precedents simply because this subpoena was issued pursuant to a criminal, as oppose to civil, investigation.”); Becker v. Kroll, 494 F.3d 904, 917 (10th Cir. 2007) (noting that the administrative subpoena was enforceable, even though it had "potential criminal ramifications," because it was "issued in good faith and prior to a recommendation for criminal prosecution"). 
inspection does not render that search illegal or the administrative scheme suspect."205 There is thus a very low barrier to a law enforcement agency referring a matter to an administrative agency. Parallel investigations do not violate civil liberties so long as the agency is not investigating solely to obtain evidence for a criminal prosecution, and did not fail to advise the defendant that a criminal prosecution has been contemplated, and there are no "other special circumstances." 206 Stated differently, courts have approved administrative proceedings that result from a criminal referral, so long as the criminal investigation did not interfere with the agency's operations, and the parallel proceedings are conducted in "good faith." 207 The reason: to hold otherwise, if "investigators suspected that a particular store might contain evidence of other crimes, the investigators would be precluded from performing any administrative inspection of that store."208 This nevertheless leaves open an obvious potential for abuse. ${ }^{209}$

There are some boundaries in place to prevent agency officials who cannot meet the higher standard from doing this with the hope or intent of transitioning to criminal liability. An agency cannot conduct an investigation when its true purpose is a criminal investigation, ${ }^{210}$ that is, an investigation that is not "for a purely administrative purpose," but rather one that "carries the real threat of criminal sanctions." 211 Courts have been mollified by the fact that "while information obtained by an administrative subpoena could be shared with prosecutors and used in a criminal investigation, grand jury secrecy would prevent information from moving in the other direction." 212 That said, other courts have suggested that an administrative warrant may be taken when the agency's aim is not solely to build a criminal case. ${ }^{213}$ Because the Supreme Court — as with most facets of investigative acts - has not addressed this question in decades, a contemporary challenge that raises these issues could result in a different outcome.

As the preceding discussion illustrates, there are many limitations in using the U.S. Constitution to deter an agency from using an improper investigatory tool or to challenge the use of such a tool. Even if a regulated entity could try to make out a Bivens ${ }^{214}$ claim on the above, damages are the only remedy though they are based on a predicate finding of unconstitutional conduct. It would not seem that a court could halt an investigation., but at least one court has commented that it was unaware of case law permitting a Bivens remedy in the context of an agency investigation. ${ }^{215}$

\footnotetext{
${ }^{205}$ New York v. Burger, 482 U.S. 691, 716 (1987).

${ }^{206}$ United States v. Kordel, 397 U.S. 1, 11-12 (1970).

${ }^{207}$ Shiv Narayan Persaud, Parallel Investigations Between Administrative and Law Enforcement Agencies: A Question of Civil Liberties, 39 U. DAYton L. REV. 77, 89-90 (2013).

${ }^{208}$ United States v. Mansour, 252 F. Supp. 3d 182, 202 (W.D.N.Y. 2017).

${ }^{209}$ Persaud, supra note 207, at 95-99 (citing possible examples).

${ }^{210}$ Id. at 716 n.27.

${ }^{211}$ Jacob v. Twp. of Bloomfield, 531 F.3d 390 (6th Cir. 2008); United States v. Theodore, 479 F.2d 749, 753 (4th Cir. 1973).

212 Berkower, supra note 90, at 2264; see FED. R. CRIM. P. 6(e).

213 See, e.g., United States v. Kordel, 397 U.S. 1, 11-12 (1970).

${ }^{214}$ Bivens v. Six Unknown Named Agents of Fed. Bureau of Narcotics, 403 U.S. 388 (1971).

215 Casella v. United States, 642 F. App'x 54, 56 (2d Cir. 2016).
} 
Putting aside whether a position is likely to succeed in the long run, the case law generally does not permit a respondent to raise any merits defenses in challenging an agency action. Finally, there is a lack of post-enforcement accountability. A motion to quash an administrative warrant may be moot where the warrant has been fully executed prior to the appeal. $^{216}$ The respondent would have to argue, for example, that the issue is evading review yet capable of repetition. Unless the party is frequently investigated by the same agency, this showing may be difficult.

\section{ii. Constitutional Separation of Powers}

The Constitution can constrain overzealous agency investigations through not just the Bill of Rights, but also its structure-of-government provisions. As Professor Nicholas Bagley has written, "Congress and the president both remain on the scene, fully capable of reforming or restraining agencies." ${ }^{217}$ Through Article I, Congress may exercise control over certain agency investigations - beyond, of course, legislating directly on the matter. ${ }^{218}$

Article I is the font from which the Supreme Court infers the Non-Delegation Doctrine. ${ }^{219}$ Some scholars hold the view that the administrative agencies have become microcosms of government unto themselves, with Article III judicial review constrained by the APA to final agency action. $^{220}$ If challengers can reinvigorate the long-dormant non-delegation doctrine, then they may be able to challenge agency investigatory methods on the basis that Congress did not intend to delegate such broad authority to the agency - depending, of course, on the exact agency, organic statute, and investigatory method used. ${ }^{221}$

Another way Congress can restrain agency investigative acts is through its oversight power. $^{222}$ Naturally, members of Congress disagree over how they want the government and its agencies to run. ${ }^{223}$ Nevertheless, "[1] egislators tend to prioritize the investigation and monitoring of executive bureaucracies," because it helps them achieve policy goals and "lets them claim

${ }^{216}$ Koppers Indus., Inc. v. EPA, 902 F.2d 756, 758 (9th Cir. 1990) (CERCLA warrant).

${ }^{217}$ Nicholas Bagley, The Procedure Fetish, 118 MicH. L. REV. 345, 351 (2019).

218 See, e.g., SEC v. Jerry T. O’Brien, Inc., 467 U.S. 735, 745-46 (1984).

${ }^{219}$ See, e.g., HICKMAN \& PIERCE, supra note 19, § 8.1 (citing FTC v. Balt. Grain Co., 284 F. 886, 888, 890 (D. Md. 1922) (overbroad delegation would be "beyond any power which Congress can confer"), aff'd, 267 U.S. 586 (1924)); Ronald A. Cass, Delegation Reconsidered: A Delegation Doctrine for the Modern Administrative State, 40 HARV. J. L. \& PUB. POL'Y 147, 178 (2017); Gary Lawson, Delegation and Original Meaning, 88 VA. L. REV. 327, 335-53 (2002).

${ }^{220}$ Gary Lawson, The Rise and Rise of the Administrative State, 107 HARV. L. REV. 1231 (1994).

${ }^{221}$ See Gundy v. United States, 139 S. Ct. 2116, 2131 (2019) (Gorsuch, J., dissenting) ("The Constitution promises that only the people's elected representatives may adopt new federal laws restricting liberty."); see id. at 2130-31 (Alito, J., concurring); Paul v. United States, 140 S. Ct. 342, 342 (2019) (Kavanaugh, J., respecting the denial of certiorari).

${ }^{222}$ U.S. ConST. art. I, § 1; see Watkins v. United States, 354 U.S. 178, 187 (1957); J.R. DeShazo \& Jody Freeman, The Congressional Competition to Control Delegated Power, 81 TEX. L. REV. 1443, 1459-66 (2003)

${ }^{223}$ Cuéllar, supra note 79, at 274-75. 
credit for making the government work more efficiently and effectively."224 Oversight can be "police patrol oversight"-more routinized oversight characterized by constant vigilance of what an agency is doing - versus "fire alarm oversight", in which Congress waits for interest groups, the public, the media, or inspectors general to draw Congress's attention to an agency problem. $^{225}$

Oversight may occur formally, by committees holding oversight hearings. For example, the House held a hearing on the Federal Trade Commission's investigation authority: "The Federal Trade Commission and Its Section 5 Authority: Prosecutor, Judge, and Jury." 226 Oversight can proceed less formally than committee and subcommittee hearings. Congressional staff can examine agency investigative practices by asking questions of the agency directly and requesting documents. ${ }^{227}$ Members can directly contact the White House for help influencing how an agency investigates. ${ }^{28}$ Congress can use its appropriations power to fund or defund the agency as a whole or parts of the agency to control how the agency conducts investigations. ${ }^{229}$ Scholars have questioned whether congressional oversight is actually effective. ${ }^{230}$ Conversely, agencies may internalize congressional oversight signaling as a mechanism to mitigate the adverse attention that flows from acting in defiance to congressional concerns. ${ }^{231}$

Congress may also, of course, enact statutes channeling or directing agency investigation processes. Reporting statutes are one example. The Government Performance and Results Act of $1993^{232}$ requires federal agencies to develop long-term strategic plans to clarify their missions, develop short-term performance plans to identify performance measures for outputs and outcomes, and report to Congress how they performed against those goals. ${ }^{233}$

Another Article I check on agency investigations is the strategic use of the Senate's confirmation powers. Officers of the United States must be appointed in accordance with Article

${ }^{224}$ Id. at 296-97.

${ }^{225}$ Id. at 297 (citing Mathew McCubbins \& Thomas Schwartz, Congressional Oversight Overlooked: Police Patrols Versus Fire Alarms, 28 AM. J. PoL. ScI. 165, 166-68 (1984)).

${ }^{226}$ See Opening Statement, Rep. Elijah E. Cummings, Ranking Member, House Committee on Oversight and Government Reform (July 24, 2014), https://oversight.house.gov/sites/democrats.oversight.house.gov/files/migrated/uploads/EEC.Ope ningStatement.072414.pdf.

${ }^{227}$ Cuéllar, supra note 79, at 297 (citing JAMES Q. WILSON, BUREAUCRACY 235-44 (1989)). ${ }^{228} I d$.

${ }^{229}$ Id.; see U.S. CONST. art. I, § 9, cl. 7.

${ }^{230}$ See, e.g., Philip J. Weiser, Entrepreneurial Administration, 97 B.U. L. REV. 2011, 2081 (2017).

${ }^{231}$ Id. at 2045; Gundy v. United States, 139 S. Ct. 2116, 2123 (2019).

${ }^{232}$ Pub. L. No. 103-62, 107 Stat. 283 (codified in scattered sections of titles 5, 31, and 39 of the U.S. Code).

${ }^{233}$ Matthew S. Schoen, Good Enough for Government Work?: The Government Performance Results Act of 1993 and Its Impact on Federal Agencies, 32 SETON HaLL LEGIS. J. 455, 456-57 (2008). 
II. $^{234}$ The Constitution thus permits Congress to freeze the consideration of nominees or reject them outright in response to agency investigations or information sharing-even indirect to the nominee or the nomination itself - that proceed contrary to Congress's wishes. ${ }^{235}$

\section{B. Statutory Constraints}

i. Administrative Procedure Act

The Constitution provides the minimum procedural and substantive rights against agency investigative acts. With the APA's prescriptive positive procedures for agency adjudication and rulemaking and its waiver of sovereign immunity to facilitate judicial review, one might assume that the statute similarly confers positive procedures for agency investigations and procedural protections to individuals who are the subject of investigative acts. As demonstrated in the chart and analysis below, the APA imposed no meaningful constraints on administrative investigation.

\begin{tabular}{|l|l|}
\hline \multicolumn{2}{|c|}{$\begin{array}{c}\text { Administrative Procedure Act Explicit Treatment of Agency } \\
\text { Investigative Acts }\end{array}$} \\
\hline \multicolumn{1}{|c|}{ APA Section } & \multicolumn{1}{c|}{ Effect } \\
\hline 5 U.S.C. § 555(c) & $\begin{array}{l}\text { Standard for administrative subpoenas: } \\
\text { must be enforced "as provided for by } \\
\text { law" }\end{array}$ \\
\hline 5 U.S.C. § 555(d) & $\begin{array}{l}\text { Procedural basis to challenge } \\
\text { administrative subpoenas and "similar } \\
\text { process or demand" }\end{array}$ \\
\hline 5 U.S.C. § 554(d) & $\begin{array}{l}\text { Miscellaneous provisions, including the } \\
\text { limited constraints on administrative } \\
\text { law judges reporting to agency } \\
\text { investigators }\end{array}$ \\
\hline
\end{tabular}

The drafting history of the APA evinces little consideration of investigative acts. ${ }^{236}$ The Supreme Court held that APA procedures available for adjudications and rulemakings do not

${ }^{234}$ U.S. CONST. art. II, $\S 2$, cl. 2.

${ }^{235}$ See, e.g., Burgess Everett \& Marianne Levine, The Senate's Record-Breaking Gridlock under Trump, POLITICO (June 8, 2020), https://www.politico.com/news/2020/06/08/senate-recordbreaking-gridlocktrump-303811?nname=playbook\&nid=0000014f-1646-d88f-a1cf5f46b7bd0000\&nrid $=00000167-e 00 b-d e a 6-a 1 f f-e a b f d b 380000 \& n l i d=630318$.

${ }^{236}$ AtTORney General's MANUAL On THE AdMinistrative Procedure ACT, supra note 111, at 66-69, 131-32. The Supreme Court has deferred to the Attorney General's Manual on the APA to the extent it does not conflict with the APA. See, e.g., Chrysler Corp. v. Brown, 441 U.S. 281, 302 n.31 (1979). 
apply to agency investigations. ${ }^{237}$ Indeed, one of the few APA provisions concerning investigative acts arise in a section entitled "Ancillary matters." 238

The APA contains investigation-specific provisions, although they have not been vigorously invoked by litigants or applied by courts. ${ }^{239}$ In 5 U.S.C. $§ 554(d)$, the APA acknowledges agency civil investigations by stating that an employee who participated in the investigation may not make a formal adjudication of the resulting matter. ${ }^{240}$ Under Section $\S 555(\mathrm{~d})$, affected parties and agencies may go to court to contest or enforce, respectively, "subp[o]ena[s] or similar process or demand." 241 These provisions were intended to leave unchanged the existing (i.e., pre-1946) law on judicial review of subpoenas. ${ }^{242}$

This part of the APA is unclear and rarely litigated - especially so in the past few decades. ${ }^{243}$ When an affected party challenges a subpoena or similar process, the few courts to consider this provision have held that the agency bears the burden to show that the subpoena is for a lawful purpose. ${ }^{244}$

The APA includes a substantive standard for a litigant to reference when invoking the cause of action available under $\S 555(\mathrm{~d})$. Under 5 U.S.C. $\S 555(\mathrm{c})$, any investigative actincluding subpoenas, process, inspection, and so forth - must be made and enforced "as authorized by law." 245 This provision appears separate from the familiar APA cause of action in 5 U.S.C. $§ 706(2)$, which provides for the setting aside of final agency action that is contrary to law or is "arbitrary or capricious." As with the procedural $\S 555(\mathrm{~d})$, litigants rarely invoke

${ }^{237}$ Hannah v. Larche, 363 U.S. 420, 452-53 (1960).

2385 U.S.C. $\S 555$.

${ }^{239}$ We note that our definition of an "investigative act" excludes an agency proceeding governed by positive APA procedures. We do not consider these Sections 555(c) and (d) to be such procedures. Otherwise, because those sections do relate to investigative acts, counting them as positive APA procedures would have the exclusion swallow the rule and exclude everything we have yet deemed to be an agency investigation.

2405 U.S.C. $\S 554(\mathrm{~d})$.

${ }^{241} I d . \S 555(\mathrm{~d})$.

242 AtTorney General's ManUal on the Administrative Procedure Act, supra note 111, at $68-69,131-32$.

${ }^{243}$ As of July 6, 2020, Westlaw recorded only 1,266 case citations to the entirety of 5 U.S.C. $\S 555$. The database shows that of those, there are only 37 cases that use the term "555(c)" or "6(b)" (which is the section of the APA codified at 5 U.S.C. $§ 555(\mathrm{c})$ ). Westlaw also shows that of those 1,266 cases, there are only 39 cases that use the term "555(d)" or "6(c)" (which is the section of the APA codified at 5 U.S.C. $\S 555(\mathrm{~d})$ ). These meager figures are overinclusive, as some of these cases cite to provisions within sections 555(c) and (d) that do not relate to investigative acts, or cite to completely distinct uses of those sections.

${ }^{244}$ United States v. Sec. State Bank \& Trust, 473 F.2d 638, 642 (5th Cir. 1973) (citing "the acceptable practice under analogous administrative schemes").

2455 U.S.C. $\S 555(c)$. 
$\S 555$ (c) to challenge agency investigations. Both have been used sparingly. ${ }^{246}$ This may be consistent with the APA drafters' expectation that this standard was a mere "restatement of existing law."247 Interestingly, the House Judiciary Committee Report broadly declared that the provision codified at $\S 555(\mathrm{c})$ was "designed to preclude 'fishing expedition' and investigations beyond the jurisdiction or authority of an agency."248 However, the enacted provision — barring investigative process "except as authorized by law" - is textually weaker than the Committee Report's remark suggests.

Nevertheless, $\S 555(\mathrm{c})$ may be significant because it is not coextensive with $\S 706(2)$, a distinct solution for challenging investigative behavior. Section 706(2) is subject to the requirement that the challenged agency conduct be "final," 249 whereas the provision for judicial review of agency investigative tools appears to be unencumbered by that qualification. ${ }^{250}$ Another constraint applicable to adjudication and rulemaking, $\S 553$, does not to apply to $\S 555(\mathrm{~d})$ actions because an investigation does not appear to be an adjudication or rulemaking under the APA's definition of those terms. ${ }^{251}$

There are several arguments to be made for applying these APA provisions to more robustly police investigative acts. The APA House Judiciary Committee Report went further than what the sparse $\S 555$ (c) and (d) case law holds. The Committee claimed that by restricting investigative acts to those "authorized by law," the APA authorized quashing investigative acts that "disturb or disrupt personal privacy, or unreasonably interfere with private occupation or enterprise." 252 The Report also warned agencies that their investigations "should be conducted so as to interfere in the least degree compatible with adequate law enforcement." 253

However, the enacted bill does not textually incorporate these principles, and these guideposts were not repeated in the influential Attorney General's Manual. ${ }^{254}$ They have been

${ }^{246}$ See, e.g., Sch. Bd. of Broward Cnty. v. Dep't of Health, Educ. \& Welfare, 525 F.2d 900, 906 n.6 (5th Cir. 1976); United States v. Morton Salt Co., 338 U.S. 632, 646 (1950) (implying a $\S 555$ (c) violation is judicially enforceable); J.H. Kent v. Hardin, 425 F.2d 1346, 1350 (5th Cir. 1970) (same); In re FTC Corp. Patterns Report Litig., No. 76-0126, 1977 WL 1438, at *2

(D.D.C. July 11, 1977) (same).

${ }^{247}$ Attorney General's MANUAL On THE Administrative Procedure ACT, supra note 111, at 66; see also AsIMOW, supra note 8, at 47 ("The provision seems to add nothing to existing law.").

${ }^{248}$ H. Rep. 1980 at 264 (May 3, 1946). One court has held that the APA does not prohibit "fishing expeditions" in and of themselves, but rather ultra vires "fishing expeditions." Pac. Westbound Conference v. United States, 332 F.2d 49, 53 (9th Cir. 1964).

2495 U.S.C. $\$ 704$.

${ }^{250}$ See id. $\S 555(c)$, (d) (not referring to judicial review "agency action," which $\S 704$ generally requires to be final).

${ }^{251}$ Id. § 551; Hannah v. Larche, 363 U.S. 420, 452-53 (1960).

${ }^{252}$ H. Rep. 1980 at 264 (May 3, 1946).

${ }^{253} \mathrm{Id}$.

${ }^{254}$ Attorney General's Manual on the Administrative Procedure Act, supra note 111, at 66 . 
cited precisely once by a federal court - in $1964 .{ }^{255}$ Further, under pre-APA case law that the Attorney General's Manual concluded was left intact by the APA, until final agency action occurs to a respondent's detriment, a court cannot determine whether the respondent is actually subject to the law the agency is purporting to enforce. ${ }^{256}$ Also, the $\S 555(\mathrm{~d})$ standard, that an agency investigation is "authorized by law," is per one court merely coextensive with the $\S 706(2)(\mathrm{A})$ "arbitrary or capricious" standard. ${ }^{257}$

There is also uncertainly as to what "law" an agency subpoena or warrant could be quashed for violating. The Attorney General's Manual states, "Law' refers to the statutes which a particular agency administers, together with relevant judicial decisions." 258 At the very least, "law" should include the Constitution. Most strictly to the affected party, some courts hold that only the organic statute can be the authorizing "law." 259 Some courts hold only federal law is the authorizing "law," not state law. ${ }^{260}$ And most strictly to the agency, some courts hold that even the agency's regulations can be the authorizing "law."261 Depending on the meaning of "law," the standards to which an agency subpoena or warrant could be held might be higher than the mere constitutional minimums discussed later.

That is the extent of APA review for a party aggrieved by an agency investigation. Standard $\S 706$ review does not apply to investigative acts because that provision requires "final agency action," which agency investigations are definitionally not. ${ }^{262}$ The Supreme Court has held that an agency's initiation of an investigation is not final agency action, ${ }^{263}$ which would reason to include antecedent investigatory acts - a decision that perhaps should have come out differently if decided today, given more recent Court cases and the analysis in this Article. Keying off that case, lower courts have held that certain investigation-related acts do not

255 Pac. Westbound Conference v. United States, 332 F.2d 49, 53 n.10 (9th Cir. 1964). ${ }^{256}$ Attorney General's MANUAL On THE AdMinistrative Procedure ACT, supra note 111, at 69 (citing Endicott Johnson Corp. v. Perkins, 317 U.S. 501 (1943); Okla. Press Pub'g Co. v. Walling, 327 U.S. 186 (1946); "Nothing the language of section 6(c) suggests any purpose to change this established rule.”). See also City of Arlington v. FCC, 568 U.S. 290 (2013) (Roberts, C.J., dissenting).

${ }^{257}$ In re FTC Corp. Patterns Report Litig., No. 76-0126, 1977 WL 1438, at *2 (D.D.C. July 11, 1977) (citing United States v. Morton Salt Co., 338 U.S. 632 (1950) and noting that that case was reviewed under $\S 555$ alone and not $\S 706$ ).

${ }^{258}$ AtTORney General's MANUAL On the Administrative Procedure ACt, supra note 111, at 69.

${ }^{259}$ Belle Fourche Pipeline Co. v. United States, 554 F. Supp. 1350, 1358 (D. Wyo. 1983); see United States v. Morton Salt Co., 338 U.S. 632, 646 (1950); see also Appeal of FTC Line of Bus. Report Litig., 595 F.2d 685 (D.C. Cir. 1978) (per curiam) (the "law" referred to is at least the agency's organic statute).

${ }^{260}$ J.H. Kent v. Hardin, 425 F.2d 1346, 1350 (5th Cir. 1970).

${ }^{261} I d$.

262 See 5 U.S.C. $\S \S 551(13), 704$.

${ }^{263}$ FTC v. Std. Oil Co., 449 U.S. 232, 239-45 (1980); Veldhoen v. U.S. Coast Guard, 35 F.3d 222, 225 (5th Cir. 1994) ("An agency's initiation of an investigation does not constitute final agency action."). 
constitute final agency action, ${ }^{264}$ including informational reports after investigation ${ }^{265}$ or certain decisions not to investigate. ${ }^{266}$

That is not to say that no agency act associated with an investigation can be a final agency action. Some courts in recent years have subverted the notion that such a bright line exists. In 2016, the Supreme Court in U.S. Army Corps of Engineers v. Hawkes Co. held that an approved jurisdictional determination by the Corps is final agency action; the affected parties had successfully argued that the determination imposed practical burdens on them and so met the test of finality. ${ }^{267}$ Agency investigatory tools could constitute final agency action if the investigation is not ad hoc, but rather the agency has developed a program, policy, or practice of investigations that crosses the line into full rule territory. ${ }^{268}$

Agency investigative acts are also arguably prosecutorial decisions (at least where the organic statute does not require the commencement of an investigation because of a specific trigger). ${ }^{269}$ This renders them presumptively unreviewable under Heckler v. Chaney or subject to the APA's discretionary fiat ${ }^{270}$ via the organic statute. The Constitution's respect for horizontal separation of powers also compels that result. ${ }^{271}$ Thus, courts generally should generally refrain from inserting themselves into decisions of how agencies should use their resources. ${ }^{272}$

But for immunity to be granted based on prosecutorial discretion, the statute must truly give the agency discretion to investigate or not investigate. The D.C. Circuit recently found justiciable the Food and Drug Administration's decision to decline to initiate certain enforcement

${ }^{264}$ E.g., Reliable Automatic Sprinkler Co. v. Consumer Prod. Safety Comm'n, 324 F.3d 726, 731 (D.C. Cir. 2003); Martin v. Naval Criminal Investigative Serv., 539 F. App'x 830, 832 (9th Cir. 2013); Mobil Exploration \& Producing U.S., Inc. v. Dep't of the Interior, 180 F.3d 1192, 1198 99 (10th Cir. 1999).

265 Parsons v. U.S. Dep't of Justice, 878 F.3d 162, 169 (6th Cir. 2017); Joshi v. Nat'1 Transp. Safety Bd., 791 F.3d 8, 11 (D.C. Cir. 2015); cf. United States v. L.A. \& Salt Lake R.R. Co., 273 U.S. 299, 309-10 (1927).

266 Jallali v. Sec'y, U.S. Dep't of Educ., 437 F. App'x 862, 865 (11th Cir. 2011).

${ }^{267}$ U.S. Army Corps of Eng'rs v. Hawkes Co., 136 S. Ct. 1807 (2016); see also Rhea Lana, Inc. v. Dep't of Labor, 824 F.3d 1023 (D.C. Cir. 2016); CSI Aviation Servs., Inc. v. U.S. Dep't of Transp., 637 F.3d 408, 412-13 (D.C. Cir. 2011)

${ }^{268}$ U.S. Dep't of Labor v. Kast Metals Corp., 744 F.2d 1147, 1150 (5th Cir. 1984).

${ }^{269}$ Gifford-Hill \& Co. v. FTC, 523 F.2d 730, 733 n.7 (D.C. Cir. 1975) (dicta); In re FTC Corp. Patterns Report Litig., No. 76-0126, 1977 WL 1438, at*3 (D.D.C. July 11, 1977).

2705 U.S.C. $\$ 701$. This is to the extent that investigative acts are not reviewable under, for example, 5 U.S.C. $\S 555(\mathrm{~d})$.

${ }^{271}$ See, e.g., Memorandum from Patrick Philbin, Deputy Assistant Att'y Gen., Office of Legal Counsel, to Daniel J. Bryant, Assistant Att'y Gen., Office of Legislative Affairs (Apr. 8, 2002); Peter L. Markowitz, Prosecutorial Discretion Power at Its Zenith: The Power to Protect Liberty, 97 B.U. L. REV. 489, 541 n.280 (2017).

${ }^{272}$ Ronald M. Levin, Understanding Unreviewability in Administrative Law, 74 MINN. L. REV. 689, 716 (1990). 
actions after the court interpreted a statute to entirely deprive the FDA of discretion to decline. ${ }^{273}$ The upshot is that Congress may, sometimes, directly cabin executive prosecutorial discretion, and by extension investigation discretion. ${ }^{274}$

Whether an agency investigation can be challenged under 5 U.S.C. $\S 555(d)$ or $\S 706$, parties have no ability to raise substantive defenses during the agency investigation that will bear on their enforcement proceeding: e.g., claims of collateral estoppel, ${ }^{275}$ allegations that the act upon which the investigation is based do not apply to respondents or that the respondents are not within the agency's jurisdiction. ${ }^{276}$ As it stands, this raises a separation of powers consideration, as Chief Justice Roberts noted in his City of Arlington v. FCC dissent. ${ }^{277}$

One benefit the APA does provide challengers is their ability to be represented by counsel at a hearing or interview. The Sixth Amendment right to counsel "does not attach until after the agency has moved beyond the investigative stage," 278 but the APA permits a party compelled to appear before an agency to be accompanied, represented, and advised by an attorney. $^{279}$

As an additional minor point, one of the APA's other few references to investigative action is its prohibition on administrative law judges being supervised by employees who investigate on behalf of the agency. ${ }^{280}$ Similarly, an investigating employee generally may not be involved in the decision except as witness or counsel. ${ }^{281}$ A violation of these structural limitations would presumably give rise to a challenge that the agency action rendered was

${ }^{273}$ Cook v. FDA, 733 F.3d 1, 7-10 (D.C. Cir. 2013).

${ }^{274}$ Citizens for Responsibility \& Ethics in Wash. v. FEC, 892 F.3d 434, 441 (D.C. Cir. 2018); see also Greer v. Chao, 492 F.3d 962, 965 (8th Cir. 2007) (quoting Giacobbi v. Biermann, 780 F. Supp. 33 (D.D.C. 1992)).

${ }^{275}$ FTC v. Texaco, Inc., 555 F.2d 862, 879 (D.C. Cir. 1977) (en banc).

${ }^{276}$ FTC v. Ken Roberts Co., 276 F.3d 538, 584 (D.C. Cir. 2001); FMC v. Port of Seattle, 521

F.2d 431 (9th Cir. 1975); SEC v. Savage, 513 F.2d 188 (7th Cir. 1975).

277568 U.S. 290, 327 (2013) (Roberts, C.J., dissenting) ("[T]here is another concern at play, no less firmly rooted in our constitutional structure. That is the obligation of the Judiciary not only to confine itself to its proper role, but to ensure that the other branches do so as well.").

${ }^{278}$ Ronald F. Wright, Organization of Adjudicative Offices in Executive Departments and Agencies, ACUS, 542 (1993), https://www.acus.gov/sites/default/files/documents/1993Statement $\% 2316 \% 20$ Organization $\% 20$ of $\% 20$ Adjudicative $\% 20$ Offices $\% 20 \mathrm{in} \% 20$ Executive $\% 20$ Departments\%20and\%20Agencies.pdf; $c f$. Middendorf v. Henry, 425 U.S. 25 (1976) (Sixth Amendment right to counsel is limited to criminal proceedings).

2795 U.S.C. $\S 555($ b).

2805 U.S.C. $\S 554(\mathrm{~d})(2)$.

${ }^{281} I d . \S 554(\mathrm{~d})$. 
unlawful for failing to observe required procedures. ${ }^{282}$ However, non-administrative law judges are not subject to these requirements. ${ }^{283}$

\section{ii. Non-APA Statutory Constraints}

Some agencies' organic statutes erect additional constraints, both in terms of substantive controls or independent oversight. ${ }^{284}$ Under the Inspector General Act of 1978, inspectors general conduct and supervise audits and investigations relating to the programs and operations" of the executive departments. ${ }^{285}$ The Inspector General Act requires the agency to give its inspector general "timely access to all records, reports, audits, reviews, documents, papers, recommendations, or other materials available to the" agency and which "relate to" the inspector general's responsibilities. ${ }^{286}$ The inspector general may also issue subpoenas, except to federal agencies. ${ }^{287}$ An inspector general may issue subpoenas to non-federal agencies and take testimony of "any person." 288

These provisions have caused friction between the inspectors general and the heads of executive agencies, particularly the Federal Bureau of Investigation. Some agency heads have contended that they alone hold the authority to release documents, and even if they do not, the agency head determines which documents are "relate[d]" to the programs and operations under review. ${ }^{289}$ Inspectors general have argued to the contrary, in favor of permitting access to agency records so that the agency cannot stonewall the inspector general. ${ }^{290}$

The Freedom of Information Act provides another bulwark. Under an earlier version of FOIA and case law from the 1970s, investigatory files remain exempt from public disclosure

${ }^{282} I d . \S 706(2)(\mathrm{D})$.

${ }^{283}$ Marcello v. Bonds, 349 U.S. 302, 311 (1955) (rejecting this challenge brought under the Due Process Clause).

${ }^{284}$ E.g., Letter from Fed. Trade Comm'n Inspector General Roslyn A. Mazer to House Committee on Oversight and Government Reform (Sept. 30, 2015), https:/causeofaction.org/wp-content/uploads/2018/10/ORIGINAL-Signed-OIG-Letter-toHOGR-staff-9-30-2015.pdf.

2855 U.S.C. app. $\S \S 1,2$, et seq. Some agencies have their inspector general authorized under other authorities. See generally CONGRESSIONAL ReSEARCH SERVICE, Statutory InsPeCtors General in the Federal Government: A Primer app. B (Jan. 3, 2019), https://crsreports.congress.gov/product/pdf/R/R45450/4.

${ }^{286}$ Id. $\S 6(\mathrm{a})(1)$.

${ }^{287} I d . \S 6(\mathrm{a})(4)$.

${ }^{288} I d . \S 6(\mathrm{a})(5)$.

${ }^{289}$ Office of the Inspector General, Statement of Michael E. Horowitz Inspector General, U.S. Department of Justice before the U.S. House of Representatives Committee on Oversight and Government Reform concerning "Obstructing Oversight: Concerns from Inspectors General”, U.S. DeP' T OF JUSTICE: OfFICE OF THE INSPECTOR GEN. (Sept. 10, 2014), https://oig.justice.gov/testimony/t140909.pdf.

${ }^{290} \mathrm{Id}$. 
even after agency proceedings terminated. ${ }^{291}$ But now, an agency must produce a requested record unless its disclosure meets one of six conditions, such as that it "could reasonably be expected to interfere with enforcement proceedings" or could disclose law enforcement techniques. ${ }^{292}$

Under that broad rubric, regulated entities can use FOIA to request information on investigations. ${ }^{293}$ For example, ProPublica has used FOIA to research the Department of Health and Human Services and the investigation close out letters it sent to healthcare providers. ${ }^{294}$ Related to FOIA, the Equal Employment Opportunity Commission releases a full set of materials contained in a charge file at the conclusion of its investigation, although apparently only to the person who filed the charge under its own statute. ${ }^{295}$ The FOIA constraint is of limited efficacy. Courts tend to defer to agencies in their assertions of exemptions. ${ }^{296}$ Agencies are disincentivized from complying with the requests. ${ }^{297}$ FOIA responses are also only as good as the information that the agency collects, which can be limited. ${ }^{298}$

Another statute that provides protections is the Privacy Act of 1974. The Act is useful not because it substantively limits how an agency undertakes its investigative acts, but because it limits the fruits of those acts - thereby serving as a backend check. This Act prohibits federal agencies from "disclos[ing] any record which is contained in a system of records by any means" to another agency unless the individual whose information is in the record consents, or if the disclosure would be for a "routine use" or for a "civil or criminal law enforcement activity" provided a certain written request is made. ${ }^{299}$ A "routine use" is defined as "the use of such record for a purpose which is compatible with the purpose for which it was collected[.]"300 The "law enforcement activity" exception is broader than criminal investigations, and does not require an active investigation or a "current law enforcement necessity." 301 The agency faces penalties for violations. For example, if an agency releases records to another agency without an exception to the Privacy Act, liability can lie against the government under the Federal Tort Claims Act. ${ }^{302}$ Relatedly, for several agencies, the agency's employees are subject to criminal

${ }^{291}$ See, e.g., SEC v. Frankel, 460 F.2d 813 (2d Cir. 1973). Accord Bristol-Myers Co. v. FTC, 424 F.2d 935 (D.C. Cir. 1970).

2925 U.S.C. $\$ 552(\mathrm{~b})(7)$.

${ }^{293}$ Margaret B. Kwoka, First-Person FOIA, 127 YALE L.J. 2204 (2018).

${ }^{294}$ Id. at 2212 (citing Charles Ornstein, The Secret Documents that Detail How Patients' Privacy Is Breached, ProPuBLICA (July 21, 2016), http://www.propublica.org/article/the-secretdocuments-that-detail-how-patients-privacy-is-breached).

${ }^{295} I d$. at 2238.

${ }^{296}$ Aram A. Gavoor \& Daniel Miktus, Oversight of Oversight: A Proposal for More Effective FOIA Reform, 66 CATH. U. L. REV. 525, 535-37 (2017).

${ }^{297} I d$. at 529-31 (describing how agencies take advantage of FOIA's ambiguities and gaps).

${ }^{298}$ Kwoka, supra note 293, at 2221.

2995 U.S.C. $\S 552 \mathrm{a}(\mathrm{b})(3),(7)$.

${ }^{300}$ Id. $\S 552 \mathrm{a}(\mathrm{a})(4)$.

${ }^{301}$ Maydak v. United States, 363 F.3d 512, 517 (D.C. Cir. 2004).

302 Doe v. DiGenova, 779 F.2d 74, 88 (D.C. Cir. 1985); see 28 U.S.C. $\S \S 1346,2671-2680$. 
penalties (fines of up to $\$ 5,000$ and imprisonment of up to a year) for disclosing any information obtained by the agency (presumably through its investigation) without the agency's authority. ${ }^{303}$ Given the difficulties and challenges that an agency faces at the end of an investigative act with collected information, the Privacy Act provides another incentive for agencies to carefully conduct their investigations and to be careful with what they do with the information obtained through their investigations.

\section{Executive Branch Constraints}

The Executive Branch can and occasionally does self-impose limiting principles to its investigative practices. The latest iteration of this behavior - at the time of this writing - is a 2020 executive order, Executive Order 13,924, Executive Order on Regulatory Relief to Support Economic Recovery, which enunciated ten "principles of fairness in administrative enforcement and adjudication" that agencies should consider in revising their "procedures and practices." 304 Most notably, Section 6(g) states that "[a]dministrative enforcement should be free of improper Government coercion." 305 The efficacy of Presidential actions to cause behavioral change is contingent on the will across executive branch agencies to enforce them as well as the variable agency-specific interpretations of the meaning of "coercion" and the types of "governmental coercion" that is "improper." 306 And, when agencies comply with executive orders, agencies" interpretations can naturally vary. ${ }^{307}$ However, in furtherance of Section 6 of Executive Order 13,924, the Office of Information and Regulatory Affairs issued an implementing memo with over twenty unique best practices for agencies to consider and apply to their rules of procedure and management. ${ }^{308}$ By December 2020, multiple cabinet agencies had modified their rules. ${ }^{309}$ As with any presidential action, Executive Order 13,924 and its corresponding implementation

${ }^{303}$ See 5 U.S.C. $\S 552 \mathrm{a}(\mathrm{i})(1)$.

${ }^{304}$ Exec. Order No. 13,924, 85 Fed. Reg. 31353 (May 19, 2020).

https://www.whitehouse.gov/presidential-actions/executive-order-regulatory-relief-supporteconomic-recovery/

${ }^{305}$ Id. $\S 6(\mathrm{~g})$.

${ }^{306}$ Peter Raven-Hansen, Making Agencies Follow Orders: Judicial Review of Agency Violations of Executive Order 12,291, 1983 DUKE L.J. 285, 290-91.

${ }^{307}$ See Udall v. Tallman, 380 U.S. 1, 4 (1965) (counseling judicial deference to reasonable agency interpretations of executive orders).

${ }^{308}$ Paul J. Ray, Administrator, Office of Information and Regulatory Affairs, M-20-31, Implementation of Section 6 of Executive Order 13924 (Aug. 31, 2020). https://www.whitehouse.gov/wp-content/uploads/2020/08/M-20-31.pdf.

${ }^{309}$ See, e.g., Susan Parker Bodine, Assistant Administrator for Enforcement and Compliance Assurance, Environmental Protection Agency, Implementation of Executive Order 13,924 (Nov. 25, 2020) https://www.epa.gov/sites/production/files/2020-

11/documents/implementationofexecutiveorder13924.pdf; Steven G. Bradbury, General Counsel, U.S. Department of Transportation, Implementation of Section 6 of Executive Order 13,924 (Nov. 13, 2020) https:/www.transportation.gov/mission/enforcement/implementation-section-6executive-order-13924. 
could be revoked in the discretion of the President, which underscores the limited benefit of executive branch constraints.

\section{Why InVestigative Acts SHOUld Be CHECKED}

Having set out what agency investigations are and how they are permitted, we now ask: Are investigative acts a good and useful thing, given the inadequate constraints under the law to advance their legitimate purpose in the constitutional system? In this Part, we aim to determine the positive and negative aspects of investigative acts. Knowing what investigative acts are capable of, and their consequences, helps inform whether more or fewer constraints on investigative acts are necessary.

\section{A. The Benefits of Agency Civil Investigative Behavior}

Agency investigations provide Americans with significant benefits. The Attorney General's Committee acknowledged this before the passage of the APA, calling it "imperative" that a "careful investigation" take place before an agency commences formal proceedings. 310 Indeed, at least for rulemaking, the Attorney General's Committee saw "the investigation, or study, of the problems to be dealt with" as one of the four distinct stages in administrative rulemaking. ${ }^{311}$ The Supreme Court, too, has noted that "it does not follow that an administrative agency charged with seeing that the laws are enforced may not have and exercise powers of original inquiry."312

Agencies execute the Executive Branch's general constitutional mandate from the confluence of organic statutes and the Take Care clause. ${ }^{313}$ The President cannot personally see to the creation and implementation of policy for the entire U.S. federal government, and consequently needs a bureaucracy to carry out the functions of the President and other officers of the United States. Agencies enforce the law and investigate numerous subjects, including fraud, ${ }^{314}$ corruption, ${ }^{315}$ forgery, ${ }^{316}$ public health. ${ }^{317}$ Agencies strive to achieve these goals in

310 Attorney General's COMmittee on Administrative Procedure, supra note 47, at 62.

${ }^{311} I d$. at 102.

312 United States v. Morton Salt Co., 338 U.S. 632, 642 (1950).

313 U.S. CONST. art. II, $\S 3$, cl. 5.

${ }^{314}$ U.S. DeP’'T OF Labor, Emp. Benefits Sec. Admin., Fact SheEt, https://www.dol.gov/sites/dolgov/files/ebsa/about-ebsa/our-activities/resource-center/factsheets/ebsa-monetary-results.pdf (last visited Dec. 17, 2020) (describing how in Fiscal Year 2018, the Employee Benefits Security Administration had enforced the Employee Retirement Income Security Act by closing 1,329 civil investigations and collecting over \$807.7 million). 315 DeP'T of State, Foreign Operations \& RElated Programs, Congressional Budget JUSTIFICATION (Mar. 11, 2019), https://www.usaid.gov/sites/default/files/documents/1868/FY_2020_CBJ.pdf. ${ }_{316}$ Id.

317 Dep’t of Health \& Human Servs., Ctrs. for Disease Control \& Prevention, JUSTIFICATION OF ESTIMATES FOR APPROPRIATION COMMITTEES, 
many situations. Evidence of a regulatory violation frequently resides solely within the hands of the regulated entity.

Investigative action helps agencies achieve their respective statutory and executive mandates. ${ }^{318}$ Accordingly, the Supreme Court has recognized that the constitutional basis for agency investigative acts "would seem clearly to be comprehended in the 'necessary and proper' clause, as incidental to both [Congress's] general legislative and its investigative powers." 319 As Professor Davis wrote the year after the enactment of the APA, "Investigations are useful for all administrative functions, not only for rule-making, adjudication, and licensing, but also for prosecuting, for supervising and directing, for determining general policy, for recommending legislation, and for purposes no more specific than illuminating obscure areas to find out what if anything should be done." 320 Professor Sunstein has argued that agencies have evolved to become "modern America's common law courts," meaning they "specify abstract standards (often involving reasonableness) and to adapt legal rules to particular contexts as facts, social understandings of facts, and underlying values change over time."321 The ability to investigate furnishes agencies with the facts to be used in such a "common law court" that are a necessary predicate to agency action. That said, as the Supreme Court recently recognized, agencies' decisions are "routinely informed" by considerations external to the affected parties: considerations of politics, foreign relations, and the national security. ${ }^{322}$ The difference in what agencies do and what agencies regulate may lead to different uses, and abuses, of agency investigations. ${ }^{323}$

Investigations can save resources for the agency and, collaterally, the regulated parties. Investigative actions allow the agency to explore whether to commence an agency action without committing to doing so and under the freedoms recognized by Heckler. An agency saves resources by looking into an issue within the agency's enforcement domain without fully committing the agency to pursuing final action. ${ }^{324}$

https://www.cdc.gov/budget/documents/fy2021/fy-2021-cdc-congressional-justification.pdf (last visited Dec. 17, 2020).

${ }^{318}$ HICKMAN \& PIERCE, supra note 19, § 8.1; Jack W. Campbell IV, Revoking the "Fishing License:" Recent Decisions Place Unwarranted Restrictions on Administrative Agencies'Power to Subpoena Personal Financial Records, 49 VAND. L. REV. 395, 396 (1996).

319 Okla. Press Pub. Co. v. Walling, 327 U.S. 186, 214 (1946).

${ }^{320}$ Davis, supra note 13, at 1111. The word "prosecution" in this quote seems to mean civil prosecution, not criminal prosecution. The APA uses the same term in a civil manner as well. 5 U.S.C. $\S 554(d)(2)$.

${ }^{321}$ Cass R. Sunstein, Is Tobacco A Drug? Administrative Agencies as Common Law Courts, 47 DUKE L.J. 1013, 1019 (1998).

322 Dep't of Commerce v. New York, 139 S. Ct. 2551, 2573 (2019).

${ }^{323}$ Bagby, supra note 7, at 349 ("The courts and the Congress should reevaluate investigatory powers if evidence mounts of abuse by either regulators or "targets."').

${ }^{324}$ Campbell, supra note 318, at 434. 
Agency investigations can serve as a platform upon which it can bring attention to issues; "[a]gencies may be able to solve collective action problems by . . . more readily generating media attention." 325 So, too, can agency investigations lead Congress to legislate. ${ }^{326}$ Agencies have been observed to use their civil powers appropriately. ${ }^{327}$ Due to the nebulous and largely non-public nature of administrative investigations, the benefits that they generate evade precise measurement: "[ $\mathrm{t}]$ he costs and benefits of government investigations are diffuse." 328

\section{B. Abuses of Agency Civil Investigative Practice}

There are numerous problematic aspects of how agencies are currently undertaking their investigatory rights, obligations, and privileges. Since the twentieth century, government agencies have been "flush with power to make highly informal decisions affecting people, where 'the usual quality of justice' may be quite low." 329 This is especially problematic where those decisions are discretionary, because agencies may find discretionary actions to be "tempting levels to create favorable perceptions," "as a sort of signal that the public (or political superiors) can use in forming judgments about the competence" of the agency. ${ }^{330}$ As the Supreme Court admonished in a 1936 opinion from the era in which the Court viewed agency investigations with skepticism, permitting an agency to compel individuals to produce evidence in the absence of jurisdiction "violates the cardinal precept upon which the constitutional safeguards of personal liberty ultimately rest," and places the government at risk of "becom[ing] an autocracy." 331

Agency investigations deploy immense investigatory power to target individuals and entities with crippling and voluminous document, inspection, and interview requests. ${ }^{332}$ The announcement of an investigation can affect share prices as well as investor and public confidence. ${ }^{333}$ When it was publicly revealed that the Department of Justice and the Federal Trade Commission were launching antitrust investigations into Facebook, Amazon, and Google's parent company, those companies' shares dropped 7.5\%, 4.6\%, and $6.1 \%$, respectively. ${ }^{334}$

${ }^{325}$ Cuéllar, supra note 79 , at 286.

${ }^{326}$ Davis, supra note 13, at 1117.

${ }^{327}$ See H.R. Rep. No. 1321, 96th Cong., 2d Sess. 4 (1980), reprinted in 1980 U.S. Code Cong. \& Ad. News 3874, 3877.

${ }^{328}$ In re Columbia/HCA Healthcare Corp. Billing Practices Litig., 293 F.3d 289, 312 (6th Cir. 2002) (Boggs, J., dissenting).

${ }^{329}$ Cuéllar, supra note 79, at 279 (citing KenNETH Culp DAVIS, DiscretionARY Justice 216 (1969)).

${ }^{330} I d$. at 263.

331 Jones v. SEC, 298 U.S. 1, 23-24 (1936).

332 Okla. Press Pub'g Co. v. Walling, 327 U.S. 186, 218-19 (1946) (Murphy, J., dissenting).

${ }^{333}$ Lauren Feiner, Facebook Tumbles on Antitrust Concerns, CNBC (June 3, 2019), https://www.cnbc.com/2019/06/03/amazon-facebook-and-google-stocks-stumble-over-antitrustconcerns.html.

${ }^{334} \mathrm{Id}$. 
Improperly scoped agency investigations can stifle individual freedoms. Once under investigation, an individual or entity may enter the orbit of criminal penalties in responding to government requests for information. A misstep in the presentation of a material fact can theoretically carry criminal consequences because making false statements in a matter within the jurisdiction of the executive branch is a crime ${ }^{335}$ as is corrupt interference in an official proceeding. ${ }^{336}$ Under the FTC's organic statute - which applies to the many other agencies for which their respective organic statutes incorporate the FTC's - a person who "neglect[s] or refuse[s]" to attend, testify, answer lawful inquiries, or produce documentary evidence in response to a federal district court order directing compliance with the agency's order commits a crime punishable by a fine up to $\$ 5,000$, or one year of imprisonment. ${ }^{337}$

Less directly, an agency can use a civil administrative investigation to bolster a parallel criminal case. ${ }^{338}$ An agency can often avoid judicial review and thereby strengthen its enforcement leverage. ${ }^{339}$ Short of criminal penalties, an agency can also take adverse action against an employee for making false statements during an investigation of alleged misconduct by the employee. ${ }^{340}$ Although the government may lawfully engage in "good faith" parallel civil

33518 U.S.C. $§ 1001$; see, e.g., United States v. Stover, 499 F. App’x 267 (4th Cir. 2012) (affirming the conviction of a mine security director who had lied during an administrative agency deposition he voluntarily sat for).

336 18 U.S.C. $\$ \S 1505,1512(\mathrm{c})$.

${ }^{337} 15$ U.S.C. $§ 50$ (Federal Trade Commission), incorporated by 7 U.S.C. $§ 1636(\mathrm{i})(3)$

(Department of Agriculture for livestock mandatory reporting); 21 U.S.C. § 467d (Food and Drug Administration to enforce poultry and poultry products inspection); 26 U.S.C. $§ 5274$ (Internal Revenue Service to enforce the collection of alcohol, tobacco, and certain other excise taxes); 27 U.S.C. $\S 202(\mathrm{~g})$ (Department of Treasury to enforce the Federal Alcohol Administration Act); 29 U.S.C. $§ 209$ (Department of Labor Wage and Hour Division to enforce the Fair Labor Standards Act). Criminal charges have been successfully brought under such statutes. See, e.g., United States v. Young, 413 F.3d 727, 728 (8th Cir. 2005).

${ }^{338}$ Anthony O'Rourke, Parallel Enforcement and Agency Interdependence, 77 MD. L. REV. 985 , 986-87 (2018) (citing the case of SAC Capital's Mathew Martoma, who was pursued by both the SEC and the U.S. Attorney's Office; "the SEC shared every document it obtained through civil discovery from SAC Capital with prosecutors," and "SEC attorneys and SDNY prosecutors also jointly conducted twenty interviews of a dozen witnesses"); Berkower, supra note 90, at 2265, 2286-87 (citing the Health Insurance Portability and Accountability Act, which "marked the first time that Congress granted th[e] broad [administrative] investigative subpoena power solely for criminal law enforcement purposes," citing a delegation to the Attorney General in 18 U.S.C. $\S 3486(\mathrm{a})(1)(\mathrm{B})(\mathrm{i})$, although as of 2005 the Attorney General had delegated this power only to AUSAs and the Criminal Division, not the Federal Bureau of Investigation, allowing them to perform a gatekeeping function).

${ }^{339}$ Rachel E. Barkow, Overseeing Agency Enforcement, 84 GEO. WASH. L. REV. 1129, 1137 (2016).

${ }^{340}$ LaChance v. Erikson, 522 U.S. 262, 268 (1998). 
and criminal investigations, the standards for "good faith" are indeterminate, and even when met the agencies may freely exchange information without prior notice to the regulated party. ${ }^{341}$

Agency investigations can pose existential threats to the regulated entities. In addition to the case of LabMD cited in Part I, ${ }^{342}$ the Consumer Product Safety Commission aggressively investigated a company that produced rare earth magnetic office-desk toys on the grounds that they were unsafe; the agency pursued personal liability against the CEO and ultimately causing the company to be dissolved and jobs to be lost while competitors continued to conduct business unabated. ${ }^{343}$

Even short of existential threats, zealous investigations can unduly vex regulated parties. The Internal Revenue Service conceded in 2013 to screening organizations' applications for taxexempt status for politically loaded terms. ${ }^{344}$ The IRS's exempt organizations office would search for conservative-associated terms like "Tea Party," "patriots," or "9/12," and progressiveleaning terms like "progressive," "occupy," and "green energy." 345 The agency would then subject such groups to heightened scrutiny and request additional information from them. ${ }^{346}$

Targets of agency investigations may not have the resources to defend against investigations or subsequent multi-year enforcement actions, and instead enter into judicially unreviewable consent decrees. All of these consequences of unsound investigative action can be exacerbated by "regulatory overlap." 347 A regulatory breach might carry both civil administrative and criminal consequences and an agency might partner with the Department of Justice to investigate. ${ }^{348}$ This could be ripe for abuse and undermine public faith in rule of law and law enforcement. For example, there is the prospect that an administrative sanction can serve as a pretext for a criminal investigation, theoretically allowing the agency and prosecutors to take advantage of the lower constitutional standard for administrative subpoenas versus criminal warrants.

\footnotetext{
${ }^{341}$ Persaud, supra note 207, at 89-90.

342 See supra Part I.

${ }^{343}$ Federal Regulators Suing Buckyballs Founder in Rare Product Recall Case, WASH. PosT (Jan. 5, 2014), https://www.washingtonpost.com/politics/federal_government/federal-regulatorssuing-buckyballs-founder-in-rare-product-recall-case/2014/01/05/5b8c19ec-5087-11e3-a7f0b790929232e1_story.html.

344 Justice Department Settles with Conservative Groups over IRS Scrutiny, REUTERS (Oct. 26, 2017), https://www.reuters.com/article/us-usa-tax-conservative/justice-department-settles-withconservative-groups-over-irs-scrutiny-idUSKBN1CV1TY.

${ }^{345}$ Id.; Alan Rappeport, In Targeting Political Groups, I.R.S. Crossed Party Lines, N.Y. TIMES (Oct. 5, 2017), https:/www.nytimes.com/2017/10/05/us/politics/irs-targeting-tea-party-liberalsdemocrats.html.

${ }^{346}$ Justice Department Settles with Conservative Groups over IRS Scrutiny, supra note 356.

347 Jody Freeman \& Jim Rossi, Agency Coordination in Shared Regulatory Space, 125 HARV. L. REV. 1131, 1138-51 (2012).

${ }^{348}$ O’Rourke, supra note 350.
} 
Scholars have identified agency over-regulation in the setting of rulemaking (and agency investigations preceding rulemaking). ${ }^{349}$ In the aggregate, regulatory overlap creates redundancy, which increases the cumulative cost of agency action and thus, presumably, the antecedent agency investigations. ${ }^{350}$ The same overlap concerns should hold true for agency investigations preceding enforcement or adjudication. That setting faces an additional problem: "multiple potential enforcers who undoubtedly already have jurisdiction over an issue might have incentives to show enforcement zeal, even if duplicating others' efforts." 351

Conversely, regulatory overlap could actually incentivize under-regulation in the face of regulatory overlap: the "regulatory commons" effect. ${ }^{352}$ Under this theory, overlapping agency jurisdiction can actually stymie agency action (and agency investigations), ${ }^{353}$ assuming that one agency has not naturally become the prime or traditional regulatory of an issue despite others' potential authority. ${ }^{354}$ There may even be some advantages to regulatory overlap and administrative crossfire, such as overcoming regulatory inertia, breaking down jurisdictional barriers, and spurring regulatory innovation. ${ }^{355}$ However, these doctrines should be viewed in consideration of modern Congresses, which have been riven with legislative torpor. ${ }^{356}$

Reputational harms may be at stake because agencies are inconsistent, sometime internally, with how they publicly address their investigative work. ${ }^{357}$ But some have called out, for example, the FTC's "practices of 'issuing news releases and the adverse effects resulting therefrom," to which the D.C. Circuit and Congress "had essentially acquiesced." ${ }^{558}$ Often, the

${ }^{349}$ See generally J.B. Ruhl \& James Salzman, Mozart and the Red Queen: The Problem of Regulatory Accretion in the Administrative State, 91 GEORGETOWN L.J. 757 (2003).

${ }^{350}$ Robert B. Ahdieh, Dialectical Regulation, 38 ConN. L. REV. 863, 897 (2006).

${ }^{351}$ William W. Buzbee, Recognizing the Regulatory Commons: A Theory of Regulatory Gaps, 89 IOWA L. REV. 1, 29 n.81 (2003).

${ }^{352} I d$. at $22,27$.

${ }^{353} \mathrm{Id}$.

${ }^{354} I d$. at 29 n. 81 .

${ }^{355}$ Catherine M. Sharkey, Agency Coordination in Consumer Protection, 2013 U. ChI. Legal F. 329, 334 (citing Ahdieh, supra note 362, at 882-83).

${ }^{356}$ See Drew DeSilver, A Productivity Scorecard for the 115th Congress: More Laws than Before, But Not More Substance, Pew ReSEARCH CTR. (Jan. 25, 2019), https://www.pewresearch.org/fact-tank/2019/01/25/a-productivity-scorecard-for-115thcongress/; Mark Murray, Unproductive Congress: How Stalemates Became the Norm in Washington DC, NBC NEws (June 30, 2013), http://firstread.nbcnews.com/_news/2013/06/30/19206400-unproductive-congress-howstalemates-became-the-norm-in-washington-dc; Michael Ellement, The Supreme Court Meets a Gridlocked Congress, 84 GeO. WASH. L. ReV. ARguendo 116 (2016).

${ }^{357}$ Nathan Cortez, Adverse Publicity by Administrative Agencies in the Internet Era, 2011 B.Y.U. L. REV. 1371.

${ }^{358}$ Id. at 1386; see Commission Closing Letters, FED. TRADE COMM'N, https://www.ftc.gov/enforcement/cases-proceedings/closing-letters-and-other-publicstatements/commission-closing-letters (last visited Dec. 17, 2020) (listing the FTC's letters announcing the close of investigations). 
reputational risk is built into the statute. If the Securities and Exchange Commission censures a business association, that entity can face additional disclosure requirements, ineligibility to obtain federal contracts, and the possibility of criminal proceedings, civil securities class actions, or shareholder derivative actions. ${ }^{359}$ Additionally, when persons affiliated with the business association (such as customers, vendors, moneylenders, shareholders, and employees) are contacted by the SEC, rumors can take root. ${ }^{360}$ The mere initiation of the investigation may be as damaging as a guilty verdict. ${ }^{361}$

Agency investigations, even when appropriate, carry significant economic costs on the public fisc and on targets. Taxpayers bear the brunt of most agency investigative costs. ${ }^{362}$ For example, for Fiscal Year 2019, the Federal Trade Commission requested an increase of $\$ 3,383,000$ for "expert witness needs due to increased numbers of complex investigations and litigation in both competition and consumer protection matters." 363 The FTC requested a total appropriation of \$309.7 million for Fiscal Year 2019. ${ }^{364}$ Under the now-lapsed Ethics in Government Act of 1978 and other authorities, independent counsel investigations, too, can cost millions of dollars to the independent counsel's office and to the target defending against the charges. $^{365}$ That said, some agencies return money to the Department of Treasury. To again use the example of the FTC, the agency returns billions annually to Treasury. ${ }^{366}$ These costs might not affect or incentivize any particular agency behavior, but their costs are important to consider in appreciating the scope of investigative acts.

Responding parties, too, can incur sizable monetary costs to respond to an investigation $^{367}$. For example, ignoring an Environmental Protection Agency information

${ }^{359}$ CORPorate Governance Avoiding AND Responding to Misconduct $\S 14.06$.

${ }^{360}$ Lewis B. Merrifield III, Investigations by the Securities and Exchange Commission, 32 Bus. LAW. 1583, 1594 (1977).

${ }^{361} I d$. Prosecutors may consider the collateral consequences of criminally prosecuting a corporate entity, which include "the possibly substantial consequences to a corporation's employees, investors, pensioners, and customers, many of whom may, depending on the size and nature of the corporation and their role in its operations, have played no role in the criminal conduct, have been unaware of it, or have been unable to prevent it." DEP'T OF JUSTICE, JUSTICE MANUAL $\S 9-28.1100 . B$, https://www.justice.gov/jm/jm-9-28000-principles-federal-prosecutionbusiness-organizations (last visited Dec. 17, 2020).

362 See, e.g., Campbell, supra note 318 , at 435.

${ }^{363}$ Fed. Trade COMM’n, Fiscal Year 2019 Congressional Budget Justification (Feb. 12, 2018), https://www.ftc.gov/system/files/documents/reports/fy-2019-congressional-budgetjustification/ftc_congressional_budget_justification_fy_2019.pdf.

${ }^{364} I d$.

${ }^{365}$ Hanly A. Ingram, United States v. Tucker: Should Independent Counsels Investigate and Prosecute Ordinary Citizens?, 86 Ky. L.J. 741, 768 (1997).

${ }^{366}$ FED. TRADE COMM'N, Fiscal YeAR 2021 CONGRESSIONAL BudGet JustifiCATION 60 (Feb. 10, 2020), https:/www.ftc.gov/system/files/documents/reports/fy-2021-congressional-budgetjustification/fy_2021_cbj_final.pdf.

${ }^{367}$ United States v. Am. Target Advert., Inc., 257 F.3d 348, 353-54 (4th Cir. 2001) (internal quotations omitted). 
request could cost up to $\$ 25,000$ per day of noncompliance. ${ }^{368}$ Not only can agencies engage in the above practices, but they may become comfortable doing so. An agency might come into the agency investigation with - or develop over the course of the investigation-outcomedeterminative bias or preordination. An agency has strong motives to do so in the absence of meaningful, systemic countermeasures.

Absent an admission from an agency decisionmaker or a judicial finding, one might not be able to conclude that a particular agency is engaging in bad practices. Agencies generally commence rulemaking procedures with an anticipated outcome-if the agency does not think the rule was fundamentally viable, it would not have started the rulemaking efforts. ${ }^{369}$ What a challenger might be able to show is that the agency is cutting corners based on precedent, past behavior, or political expediency. ${ }^{370}$ But it is very difficult to prove an unalterably closed mind. ${ }^{371}$ Even when the Supreme Court held the Secretary of Commerce had improperly used pretext to justify its asking of a new census question, it did not conclude that was foreclosed from reconsidering. ${ }^{372}$

Another harm from improper agency investigations is more abstract: constitutional horizontal separation of powers concerns. Many administrative agencies operate in a zone that is free of oversight from both the policy prerogatives of the First Branch and the oversight of the Third Branch, especially if the organic statute provides no guidelines or Article III review of investigative practices. The result, anecdotally and systemically, is the risk of tyrannical behavior by agencies and within them, bureaucrats who are not politically accountable as principal or inferior officers of the United States under the Appointments Clause. ${ }^{373}$

A key caveat must be reinforced in this assessment of the harms of overzealous agency investigations: it is impossible to know the full extent of how agencies are investigating. To the extent such information even could be aggregated, agencies rarely report it publicly, such that one could readily research it. Agencies generally do not report who and how they are investigating. ${ }^{374}$ Thus, not every agency will announce the commencement of an investigation,

${ }^{368}$ United States v. Gurley, 384 F.3d 316, 324 (6th Cir. 2004) (validating the assessment of civil penalties of up to $\$ 25,000$ per day for noncompliance per 42 U.S.C. $\S 9604(\mathrm{e})(5)(\mathrm{B})$, and affirming the levy of a smaller amount against a defendant, $\$ 1.9$ million for seven years of willful noncompliance).

369 See Dep’t of Commerce v. New York, 139 S. Ct. 2551, 2573 (2019); FTC v. Cement Institute, 333 U.S. 683, 700-03 (1948).

${ }^{370}$ United States ex rel. Accardi v. Shaughnessy, 347 U.S. 260, 265-66 (1954) (holding that an agency must follow its own regulations).

${ }^{371}$ Air Transp. Ass'n of Am., Inc. v. Nat'1 Mediation Bd., 663 F.3d 476, 487-488 (D.C. Cir. 2011).

372 Dep’t of Commerce v. New York, 139 S. Ct. 2551, 2573-76 (2019).

${ }^{373}$ See Jennifer L. Mascott, Who Are “Officers of the United States”?, 70 Stan. L. REV. 443 (2018).

${ }^{374}$ For instance, "[i]n general, the Department of Justice does not publicly announce investigations or investigative findings." U.S. DeP'T OF Justice, CIVIL Rights Div., When Does the Division Announce Investigations?, https://www.justice.gov/crt/when-does-division- 
detail an expansion of the investigation's scope, or issue close-out letters. ${ }^{375}$ Even when an agency provides a "cold comfort letter" announcing that it harbors no present intentions to take additional enforcement action against an entity, such letters are often not enforceable and give no indication as to when an investigation might come back to life. ${ }^{376}$

This potential for the above abuse is real and has been occasionally recognized since the rise of the Administrative State. Over 70 years ago, Justice Murphy, dissenting in Oklahoma Press Publishing Co. v. Walling, noted with trepidation the metastatic growth of the administrative state (which has only accelerated since he wrote in 1946). ${ }^{377} \mathrm{He}$ implored agency investigators to feel "a new and broader sense of responsibility," lest they succumb to the "open invitation to abuse" the immense power of agency investigations and repeat the missteps of the pre-Revolution British monarchy. ${ }^{378}$ "Only by confining the subpoena power exclusively to the judiciary," Justice Murphy opined, "can there be any insurance against this corrosion of liberty." 379

The concurrences in the 1985 Heckler v. Chaney opinion expressed trepidation that the majority opinion "empowered" agencies to administratively close investigations. Justice Brennan, concurring, listed circumstances in which he believed that, statutory language aside, non-enforcement decisions should be reviewable. ${ }^{380}$ Justice Marshall's separate concurrence went further, arguing that district courts had invented remedies aimed at agencies to ensure "administrative fidelity to congressional objectives." 381 In his view, the majority"s creation of a "presumption of unreviewability" was an act of the Supreme Court failing to use "a scalpel rather than a blunderbuss" to correct those remedies Justice Marshall posited that "[t]raditional principles of rationality and fair process do offer 'meaningful standards' and 'law to apply' to an

announce-investigations (last updated Oct. 18, 2018). The Department of Justice justifies its policy by citing the possibility that a premature announcement may impair the Department's ability to build a case, as well as the possible prejudice to the responding party. Id. However, the Department may announce investigations when they result in enforcement action or when law enforcement entities are involved. Id.

${ }^{375}$ Some agencies do, after the fact, report certain statistics on investigations opened, for example, the Department of Justice's Antitrust Division. U.S. DEP'T OF JUSTICE, ANTITRUST DiV., WORKLOAD STATISTICS, https://www.justice.gov/atr/file/788426/download (last visited Dec. 17, 2020).

${ }^{376}$ Fresenius Medical Care v. United States, 526 F.3d 372, 374-76 (8th Cir. 2008); Jonathan Cone et al., Negotiating False Claims Act Settlements, 14-3 BRPAPERS 1, 14-3 Briefing Papers 1, 10 (2014); see, e.g., Debtors' Mot. For Entry of an Order Authorizing, but Not Directing, the Debtors' Entry into the Settlement Agreement \& Approving the Settlement of the Qui Tam Claims and Related Matters, In re Trident Holding Co., No. 19-10384 (Bankr. S.D.N.Y. filed Aug. 29, 2019), Dkt. 837.

377 Okla. Press Pub'g Co. v. Walling, 327 U.S. 186, 218 (1950) (Murphy, J., dissenting).

${ }^{378}$ Id. at $218-19$.

${ }^{379}$ Id. at 219.

${ }^{380}$ Heckler v. Chaney, 470 U.S. 821, 839 (1985) (Brennan, J. concurring) (internal citations omitted).

${ }^{381} I d$. at 852 (Marshall, J., concurring in judgment only). 
agency's decision not to act, and no presumption of unreviewability should be allowed to trump these principles." 382

Justice Marshall's points may gain greater force when read in light of one of the majority's key justifications and considering how that justification has aged. The majority concluded that agency exercises of administrative civil prosecutorial discretion are presumptively non-reviewable, as "[a]n agency generally cannot act against each technical violation of the statute it is charged with enforcing." "383 As showcased above, the empirical predicate of Heckler may be eroding, especially in light of the possibility of technologyfacilitated total enforcement. At minimum, it is a clear expression of the Court justifying its holding based on an agency's limited ability to enforce at high volumes, which implies a similar limitation on its ability to investigate.

The above harms are all the more important to study considering the potential for disruptive new technologies to increase agencies' abilities to investigate. The deployment of machine learning ${ }^{384}$ and other artificial intelligence-based technologies that are already pervasive in the criminal justice system ${ }^{385}$ have begun to change the Administrative State. Researchers recently applied machine learning to analyze existing satellite data to identify previously unknown industrial animal farms known in North Carolina for Clean Water Act enforcement. ${ }^{386}$ This transaction evidences how transformative, scalable, and affordable artificial intelligence can be for administrative investigative practices. ${ }^{387}$ By replicating and improving upon human cognitive and personnel capability, artificial intelligence harkens the possibility of a total enforcement environment where many more regulatory violations could be brought to account. ${ }^{388}$

${ }^{382}$ Id. at 854 .

${ }^{383} \mathrm{Id}$. at 831 (majority op.).

384 "Machine learning" is a type of artificial intelligence that uses algorithms to construct computer models that analyze large data sets, typically to predict the future. See Federal Agency Data Mining Reporting Act of 2007, 42 U.S.C. § 2000ee-3(b)(1)(A) (2012) ("The term 'data mining' means a program involving pattern-based queries, searches, or other analyses of 1 or more electronic databases . . . to discover or locate a predictive pattern or anomaly indicative of terrorist or criminal activity ....")

${ }^{385}$ Emily Berman, A Government of Laws and Not of Machines, 98 B.U. L. REV. 1277, 1293 (2018).

${ }^{386}$ Laura Poppick, Environment Watchdogs Harness AI to Track Overflowing Factory-Farm Waste, SCIENTIFIC AMERICAN (Apr. 11, 2019), https://www.scientificamerican.com/article/environment-watchdogs-harness-ai-to-trackoverflowing-factory-farm-waste/.

${ }^{387}$ Harry Surden, Machine Learning and Law, 89 WASH. L. REV. 87, 88 (2014) ("In the last few decades, researchers have successfully used machine learning to automate a variety of sophisticated tasks that were previously presumed to require human cognition."). These tasks include language translation, vehicle driving, revealing bank fraud, calculating credit risk, and so forth.

${ }^{388}$ The seminal case that rendered administrative prosecutorial discretion presumptively unreviewable was undergirded by an assumption that "agency generally cannot act against each 
In light of this exercise of administrative power, it is necessary to consider the limiting principles that are in place to guide agencies in the increasing likely hypothetical scenario in which one decides to run an inspection-enforcement program that involves mailing packages full of machine sight-enabled drones to map, examine, and inspect a warehouse and every product running in an assembly line, and then transmit the data on a $5 \mathrm{G}$ wireless network to a government supercomputer that is running a deep learning ${ }^{389}$ algorithm to test the possible violation of numerous statutes and regulations.

In sum, while investigative acts are necessary to agencies fulfilling their constitutional and statutory duties, they also open the door to unaccountable abuse.

\section{ApPlying MeAningful CONSTRAints to AgEnCy InVESTigations}

As this Article has demonstrated, there is no currently-applied meaningful constraint to investigative acts that violate the Constitution or statutes. Professor Davis observed 73 years ago that "[n]arrow judicial interpretations have given rise to strikingly large grants of power." 390 His observation remains correct today. As applied by the courts, the APA does not provide for meaningful or timely judicial review to challenge agency subpoenas or other process due to the "authorized by law" substantive standard. While that phrase is textually capacious, courts have construed it narrowly. The marginally less deferential $\S 706(2)$ judicial review provision of the APA, which assesses whether an agency act is "arbitrary or capricious," is hamstrung by the requirement that the tool be "final agency action."

Since 1950, the Supreme Court has given little effect to many of the individual liberty provisions of the Constitution, which are incorporated by the APA's "authorized by law" standard. The standards that apply to agency subpoenas, warrants, or other investigative techniques need only meet minimal thresholds such as be not "unduly burdensome," or "reasonably relevant." Regulated entities should recognize and use other tools to shed light on the murky area of agency investigations.

First, individuals and entities should make more robust use of existing judicial constraints and push courts to expand the boundaries of judicial review. ${ }^{391}$ This is not an easy task, given courts' tendencies to uphold investigative acts under the thinking that "[j] udicial supervision of agency decisions to investigate might hopelessly entangle the courts in areas that would prove to

technical violation of the statute it is charged with enforcing." Heckler v. Chaney, 470 U.S. 821, 831 (1985).

${ }^{389}$ Deep learning is a term for a strand of AI processes by which a computer program refines its own internal models to improve its ability to process a set of information. LeCun, Bengio, \& Hinton, Deep Learning, 521 NATURE 436 (2015).

${ }^{390}$ Davis, supra note 13, at 1117.

${ }^{391}$ Rachel E. Barkow, Overseeing Agency Enforcement, 84 GEO. WASH. L. REV. 1129, 1162 (2016) (describing advantages of judicial review of agency enforcement practices). 
be unmanageable and would certainly throw great amounts of sand into the gears of the administrative process." 392

The greatest potential source of assistance for helping guard against abusive agency investigations may be the Fourth Amendment. The Supreme Court, upon being confronted with the issue, should revisit the current state of the law by more closely reviewing agencies' interpretations of their investigations and investigative acts. ${ }^{393}$

To accomplish that, courts could create a better remedy for an overbroad, burdensome, or ultra vires subpoena or warrant. The current review regime is almost unassailably deferential to the agency, offers a remedy of simply having the agency limit the scope of the subpoena, and makes the respondent wait until the commencement and termination of agency adjudication to be able to challenge the agency, at which point the challenge can be practically, if not legally, moot. Courts can simply grant declaratory relief to plaintiffs with limiting instructions. More careful Fourth Amendment scrutiny would deter the agency from being overbroad or needlessly intrusive from the start, especially given the disincentives responding parties face to contesting such improper investigative acts. ${ }^{394}$ Litigants and judges should also pay very close attention to the agencies' enabling statutes and ensure that agency investigative powers are authorized by the statute. More modern views of statutory interpretation techniques since Oklahoma Press Publishing and Morton Salt could lead courts to arrive at new conclusions about what, precisely, Congress has actually authorized an agency to do with regard to an individual or entity it is investigating. Relatedly, a challenger might seek reexamination of a 1947 Supreme Court decision that absent an explicit statutory prohibition, an agency head may delegate down the chain of command to sign and issue subpoenas. ${ }^{395}$

The Supreme Court should balance the separated powers against the odd and problematic state of administrative law, today. These constitutional arguments are not wholly new. The Supreme Court endorsed them in pre-World War II cases, when the Court was much more skeptical of agency investigatory techniques. ${ }^{396}$ A resurgence of those cases' reasoning would help rein in abusive investigations. One part of that resurgence could perhaps be the resurrection of the Supreme Court's limitation of subpoenas to where "the sacrifice of privacy is necessarythose where the investigations concern a specific breach of the law."397 Litigants could also appeal to the Court's bygone concern of roving inquiries into regulated parties' records and

\footnotetext{
${ }^{392}$ SEC v. Wheeling-Pittsburgh Steel Corp., 648 F.2d 118, 127 n.12 (3d Cir. 1981) (en banc) (quoting Dresser Indus., Inc. v. United States, 596 F.2d 1231, 1235 n.1 (5th Cir. 1979)).

393 Persaud, supra note 207, at 89-90.

${ }^{394}$ See Robert L. Glicksman \& Emily Hammond, The Administrative Law of Regulatory Slop and Strategy, 68 DUKE L.J. 1651, 1686-88 (2019) (arguing for remedies to clean up "regulatory slop," such as fee-shifting provisions, injunctions, tailored instructions on remand, and the contempt power).

${ }^{395}$ Fleming v. Mohawk Wrecking \& Lumber Co., 331 U.S. 111, 121-22 (1947).

${ }^{396}$ Scherb, supra note 136, at 1079.

${ }^{397}$ Harriman v. Interstate Commerce Commission, 211 U.S. 407, 419-20 (1908) (emphasis added).
} 
conduct, which it previously deemed as "contrary to the first principles of justice." 398 Those barriers fell with Oklahoma Press Publishing in 1946, ${ }^{399}$ but they could be restored. Such a view would dovetail with the recent, general judicial evolution toward closer inspection of agency activity. ${ }^{400}$

Specifically, the Court should revisit Oklahoma Press Publishing and Morton Salt, which discounted stare decisis to make the very deferential Fourth Amendment case law in force today. The Court should apply a standard for quashing agency subpoenas or warrants with fidelity to the requirement that only the organic statute provides the agency authority to perform an investigative act. In so doing, the Court should eschew constraints such as the limitation that investigative acts not be performed in "bad faith," which arguably reserves discretion for judges to be lax in policing the use of investigative acts. The Court should consider setting probable cause as the standard for issuing an administrative warrant, especially given the potential for a civil investigation founded on an administrative warrant to morph into a criminal investigation. ${ }^{401}$ Courts should also prohibit administratively-obtained investigative materials from being used against the producing party in a criminal case unless such material could have been obtained in a criminal investigation under the Fourth Amendment.

The Fifth Amendment should be reinvigorated in this arena. Courts should recognize a due process property and liberty interest to more-robustly challenge an administrative investigation that is onerous and abusive. This could be a corollary to the current Fourth Amendment defense against unduly burdensome investigations. This interest might protect, for example, parties from having to produce privileged information to agencies. ${ }^{402}$

This constitutional landscape will be difficult to shape. Litigants may have greater success with the APA, though the Court has been increasingly willing to robustly review administrative authority as of late. ${ }^{403}$ The APA's provision for challenging agency subpoenas, warrants, and other process, 5 U.S.C. $§ 555(c)$ and (d), is very rarely used, especially in the past few decades. Litigants could breathe new life into these provisions and help develop case law into its meaning. These provisions are textually not limited by the final-agency-action requirement, and so could be used in lieu of, or in addition to, the more broadly available provision for challenging agency action, 5 U.S.C. $\S 706$. Of course, this provision may not be as helpful to affected parties as they may like, though, because the Fourth Amendment already permits respondents to challenge subpoenas and warrants on the ground that the agency lacks the authority to issue them.

\footnotetext{
${ }^{398}$ FTC v. Am. Tobacco Co., 264 U.S. 298, 306 (1924).

${ }^{399}$ HiCKMAN \& PIERCE, supra note 19, at $\S 8.1$ (5th ed. 2010).

${ }^{400}$ See, e.g., Kisor v. Wilkie, 139 S. Ct. 2440 (2019).

${ }^{401}$ See Marshall v. Barlow's, Inc., 436 U.S. 307, 320 (1978).

402 See supra note 154.
}

${ }^{403}$ Gillian Metzger, The Roberts Court and Administrative Law, 2019 SuP. CT. REV. 1, 1 ("Administrative law today is marked by the legal equivalent of mortal combat, where foundational principles are fiercely disputed and basic doctrines are offered up for 'execution"'). 
Litigants may consider arguing for a more robust interpretation of $\S 555(\mathrm{c})$, which states that investigative acts must be "authorized by law." ${ }^{\text {"04 }}$ A more respondent-friendly interpretation of $\S 555(\mathrm{c})$ might accord with the APA House Judiciary Committee Report, which stated that APA investigative acts not only had to fall within the agency's jurisdiction, but also had to respect, to the greatest reasonable degree, personal privacy and industry. ${ }^{405}$ To avail itself of the House Judiciary Committee Report language, a party does not have the benefit of case lawwhich appears to have cited, but not applied, this language only once. ${ }^{406}$ But, such party can point to the fact that the Supreme Court has cited the House Judiciary Committee Report with approval, if not dispositive weight. ${ }^{407}$ This may be the only way to argue that $\S 555(\mathrm{c})$ is a hook to challenge an investigation as coercive or an abusive use of prosecutorial discretion, which we believe is a reason to curb an agency investigation.

An affected party could argue that a broad agency investigation impermissibly blurs the separation of powers and is thus not authorized by law. A court could quash the investigatory tool on that basis. This aligns with a recent opinion authored by a Justice in the space of nondelegation doctrine, where administrative law impacts on significant national issues tie, arguably fatally, into broader separation of powers considerations. ${ }^{408}$

One semi-efficacious mechanism for entertaining §555(d) challenges could be the judicial imposition of a "clear statement" requirement as a canon of construction. That is, a statute should have to clearly and expressly provide the agency with particular investigatory powers - a general delegation of authority for rulemaking or adjudication would not suffice. On the aggregate, this approach would benefit privacy and private interests as courts fail to find investigative authority in vague or empty legislative delegations and as Congress's likely inertia or inaction fails to respond.

A "clear statement" requirement would shift the burden from the respondent to the agency. This approach would be consistent with other "clear statement" canons the Court has imposed to protect constitutional values, for example the presumption against retroactivity, ${ }^{409}$ or the presumption in favor of judicial review. ${ }^{410}$ Requiring such a canon here would be compatible with these more recent cases and present an avenue to develop the law in a way that does not

4045 U.S.C. $\$ 555(\mathrm{c})$.

${ }^{405}$ H. Rep. 1980 at 264 (May 3, 1946).

${ }^{406}$ See Pac. Westbound Conference v. United States, 332 F.2d 49, 53 n.10 (9th Cir. 1964).

Davis, supra note 13, at 1134; AsIMOW, supra note 8, at 47 ("[Section 555(c)] seems to add nothing to existing law.”); see also FTC v. Am. Tobacco Co., 264 U.S. at 305-06.

${ }^{407}$ See Merck Sharp \& Dohme Corp. v. Albrecht, 139 S. Ct. 1668, 1680 (2019); Chrysler Corp. v. Brown, 441 U.S. 281, 313 (1979); see also Kisor v. Wilkie, 139 S. Ct. 2400, 2436 (2019) (Gorsuch, J., concurring).

${ }^{408}$ Paul v. United States, 140 S. Ct. 342, 342 (2019) (Kavanaugh, J., respecting the denial of certiorari)

${ }^{409}$ Bowen v. Georgetown Univ. Hosp. 488 U.S. 204 (1988).

${ }^{410}$ Dep't of Homeland Sec. v. Regents of Univ. of Cal., 140 S. Ct. 1891, 1905-06 (2020). 
squarely challenge stare decisis. ${ }^{411}$ Finally, a statement would heed the Attorney General Committee's warning from almost 80 years ago that the power to procure information "should not be withheld" from administrative agencies when needed, "but it should be exercised with restraint and with knowledge that the burden imposed is a mounting one."412

A court's careful canvass of the text and legislative history of the agency's enabling statute would help ensure that Congress in fact intended to give the agency the power of investigation. Affected parties should also try to make more of $\S 706$ challenges. They could advocate for styling an administrative investigation as adjudication (either categorically or on a case-by-case basis). Then, certain requests, such as a massive document search, could be classified as a final agency action, especially in the context of adverse consequences for noncompliance. The Supreme Court might also conclude that agency investigations, as we have defined them - with the elements of coercion and affirmative steps - are APA final agency actions.

That may be difficult in terms of the current $\S 704$ finality case law from the Supreme Court and circuit courts. But as noted earlier, recent Supreme Court decisions have softened $\S 704$ 's final action barrier as a response to this problem, including by viewing some closing letters as final agency action. ${ }^{413}$ A closing letter is different from a decision to initiate an investigation. As the Sixth Circuit has held, Hawkes may be distinguishable; if the agency's report or determination had legal consequences like prohibiting the agency from bringing enforcement proceedings or denying the respondent legal safe harbor, then it is final agency action. But if further decisionmaking is available, then it may not be final agency action. ${ }^{414}$

The extra-statutory "exceptional circumstances" exception to finality might also yield helpful new constraints on agency investigations. Specific investigatory tactics might also be final agency action. ${ }^{415}$ Individuals should keep an eye for when investigatory patterns emerge such that the policy or practice could itself be challenged under the APA on an as-applied basis to the individual and for failure to comply with rulemaking strictures. For example, an AIassisted forensic review of an entire database might be such a concrete and widespread act by an agency as to constitute a substantive rule, for which notice-and-comment rulemaking is required and judicial review is available. ${ }^{416}$

411 This approach would also vindicate Justice Marshall's concerns in his Heckler v. Chaney concurrence about ensuring "administrative fidelity to congressional objectives." Heckler v. Chaney, 470 U.S. 821, 852 (1985) (Marshall, J., concurring in the judgment only).

412 AtTorney General's COMMITTEE ON ADMINISTRATIVE ProcedURE, supra note 47, at 114.

${ }^{413}$ See, e.g., Sackett v. EPA, 566 U.S. 120 (2012) (holding that EPA compliance orders are final agency action).

${ }^{414}$ Parsons v. U.S. Dep't of Justice, 878 F.3d 162, 170-71 (6th Cir. 2017).

415 See Veldhoen v. U.S. Coast Guard, 35 F.3d 222, 225 (5th Cir. 1994) ("Normally, the plaintiff must await resolution of the agency's inquiry and challenge the final agency decision.").

416 See HiCKMAN \& PIERCE, supra note 19, at $\$ 8.1$ (chronicling the sometimes hazy line between adjudications and rules, but noting that being addressed to unnamed classes of individuals not presently before the agency is a hallmark of rules). 
Second, individuals and entities should avail themselves of the political process. An agency investigation presumably ought to be typically centered around some discrete body of individuals. The more individuals targeted by an agency, the more effectively those individuals have access to political machinery to resolve an issue. The Internal Revenue Service scandal involving the targeting of political-sounding groups seeking tax-exempt status riled enough groups and representatives that the agency settled a lawsuit and apologized, and its commissioner resigned. But our concern is with the absence of countermajoritarian protections, the rights of the individual or near-individual.

Third, Congress should consider legislative fixes. We recognize the political reality that prospective legislation of this sort presents for actual passage into law is a major challenge. The impetus for this might be analogous to when Congress let the independent counsel statute ${ }^{417}$ lapse. The history suggests that the law's critics of both parties complained that the independent counsel wasted taxpayer money while pursuing offenses short of "high crimes and misdemeanors" and while trampling on individual rights. ${ }^{418}$ Then-Deputy Attorney General Eric H. Holder, Jr., appears to have testified that a continuation of the special counsel statute was unnecessary, as the Department of Justice can investigate most crimes itself. ${ }^{419}$ Thus, Congress would need to free itself of this thinking if it were to consider that agencies might not, in fact, be the best guards of their own investigatory behavior.

Specifically, Congress could go beyond the minimum requirements of Fourth Amendment or other constitutional provisions. Congress could enshrine substantive objections or new procedural vehicles into the APA. Although no member appears to have introduced a bill on the subject in recent Congresses, the Administrative Conference of the United States ("ACUS") could be a model. In December 2016, the Adjudication Committee of ACUS recommended new procedures for evidentiary hearings not required by the APA that are presided over by administrative law judges. ${ }^{420}$ Of note, ACUS recommended:

- Agencies should separate their internal functions. The personnel who investigate, prosecute, and advocate should not also serve an adjudicatory function ${ }^{421}$

- Agencies should engage in discovery with rules closer to those contained in the Federal Rules of Civil Procedure, including an agency showing of need and cost justification. ${ }^{422}$ (We add requiring the agencies to adhere to "proportionality," such as used in Federal

${ }^{417} 28$ U.S.C. $\$ \S 591-599$ (1994) (expired).

${ }^{418}$ David Stout \& David Johnston, Justice Officials to Call for End to Counsel Law, N.Y. TIMES, Mar. 2, 1999.

${ }^{419}$ Id.

${ }^{420}$ Administrative Conference of the United States, Evidentiary Hearings Not REQUIRED BY THE ADMINISTRATIVE PROCEDURE ACT (Dec. 15, 2016), https://www.acus.gov/recommendation/evidentiary-hearings-not-required-administrativeprocedure-act.

${ }^{421} I d$.

${ }^{422} I d$. 
Rule of Civil Procedure 26(b) ${ }^{423}$ could help properly focus their investigative acts, particularly where the information sought may be primarily electronically stored.)

- Agencies with subpoena or other process power fully detail their subpoena practice. ${ }^{424}$

- Agencies should develop rules of evidence. ${ }^{425}$

- Agency should provide written or transcribable decisions, and decisions should be made precedential. $^{426}$

ACUS's recommendations appear to be sound, or at least are good templates for the sort of reform that Congress should consider to increase transparency in the civil administrative investigation process.

The First Branch could amend agencies' organic statutes to clarify or limit their investigatory authorities to ensure they are in compliance with congressional intent and are wellproportioned to the agency's mission. Congress could refocus agency priorities by explicitly separating compensation and advancement metrics from violation-centered outcomes. That is, agency employees or the agency as a whole should not receive incentives for pursuing investigations that result in enforcement actions. Congress should consider limiting an agency's ability to initiate additional investigations after commencing adjudication, to prevent the pressure of additional investigations from coercing settlement or acquiescence.

Relatedly, the Equal Access to Justice Act ("EAJA"), which provides for attorneys' fees to certain prevailing private parties in "civil actions" against the federal government, could be amended. ${ }^{427}$ The APA has a similar provision for prevailing parties in adversary adjudications. ${ }^{428}$ These provisions could explicitly apply to $\S 555$ (d) challenges of agency investigatory tools. Congress could expand EAJA accessibility for attorney's costs and fees associated with pre-litigation investigations and enforcement actions. ${ }^{429}$

Congress could also reform the oversight process; if regulated entities are not able to hold overzealous investigating agencies accountable, then other government actors should be able to. The Department of Justice has commended judicial review of administrative subpoenas, saying, "judicial involvement in enforcement ensures a good degree of fairness." 430 Funding more inspectors general or expanding their powers might positively impact the oversight process. ${ }^{431}$ Congress could also require agencies to report more data on investigations they have begun,

${ }^{423}$ FED R. CIV. P. 26(b)(1).

${ }^{424}$ AdMinistrative CONFERENCE OF THE United StATES, supra note 4201.

${ }^{425} \mathrm{Id}$.

${ }^{426} \mathrm{Id}$.

42728 U.S.C. $\$ 2412$.

4285 U.S.C. $\$ 504$.

${ }^{429}$ The latest edition of the EAJA model rules by ACUS, for what it is worth, do not include any sort of expansion. See Administrative Conference of the United States, supra note 431.

${ }^{430}$ RePort to Congress ON THE USE OF AdMINISTRATIVE SubPoENA Authorities By Executive Branch Agencies and Entities, U.S. Dep't of Justice, OfFice OF Legal Policy apps. (2002), https://www.justice.gov/archive/olp/rpt_to_congress.htm\#4.

${ }^{431}$ Cuéllar, supra note 79, at 299. 
including the steps undertaken in pursuit of the investigation and the eventual result of the investigation. Even if that information is not made public, simply having this information would better enable Congress - and agency heads - to determine whether agency investigators are acting in accordance with the Constitution, the organic statute, and principles of good governance.

Finally, agencies themselves could self-regulate and impose durable constraints on themselves through the rulemaking process. Regulations defining the scope of an agency's investigation, and creating procedural opportunities for responding parties to contest an investigation's scope or methods, are not unheard of. For example, the Securities and Exchange Commission has a regulation that provides, "Persons who become involved in ... [SEC] investigations may ... submit a written statement to the Commission setting forth their interests and position in regard to the subject matter of the investigation." 432

Of course, an agency would seem to have little incentive to voluntarily make rules reining in its investigative authority. This is especially so given the costs to the agency of even making the rule. However, there is historical precedent; agencies, especially before the APA was enacted, not infrequently developed standards of conduct which they committed to follow. ${ }^{433}$ Even if an agency does not want to self-regulate, respondents have at least two possible routes to pressure the agency to do so. Respondents could submit comments urging the adopting of selfscoping rules when the agency is considering related rules. Respondents could also petition the agency to make these rules under the APA's petition procedure. ${ }^{434}$ This would help craft new equipment with which to detect and study the unknown nuances of administrative investigations.

\section{CONCLUSION}

The field of administrative investigations is broad and under-researched. This Article endeavors to identify and to establish a framework to explore the space with the knowledge that its depths lie unknown. We have concluded that each branch of federal government that has enabled administrative investigations to flourish unbounded can take discrete steps to bring them back to constitutional alignment.

Given the abuses agencies have engaged in and the potential for new technologies to expand how investigations proceed, it is important that such controls be implemented in the near future. Congress, with its plenary primacy on the policy and powers of the administrative state, ought to take first chair to reform the Administrative Procedure Act. Congress should establish positive procedures that investigating agencies must follow and explicitly create a cause of action for individuals and entities of the regulated public to access the courts for inappropriate exercise of administrative investigative power. The executive branch should establish durable controls of self-restraint so that the American people are treated fairly when agencies act under Article II to "take Care that the Laws be faithfully executed." 435 The Judiciary should remedy its

\footnotetext{
43217 C.F.R. $\S 202.5(\mathrm{c})$.

${ }^{433}$ Cuéllar, supra note 20, at 1409-10.

4345 U.S.C. $\S 553(\mathrm{e})$.

${ }^{435}$ U.S. CONST. art. II, $\S 3$, cl. 5.
} 
errors in United States v. Morton Salt Co. and Oklahoma Press Publishing Co. v. Walling ${ }^{436}$ to enforce normative constitutional constraints on administrative behavior. It should reassess the procedural and substantive protections of the APA in line with its legislative history.

Lastly, the American public should be more cognizant of their lack of rights in the face of administrative investigative power and take steps politically and legally to press for their restoration, especially in the face of unchecked investigations like those against LabMD. It is likely that the march of technology and the application of cutting-edge artificial intelligence strands like machine learning and deep learning to administrative investigations will serve as a catalyst for these actions. Until then, American society will slowly lose more of their rights.

436 United States v. Morton Salt Co., 338 U.S. 632, 652 (1950); Okla. Press Pub'g Co. v. Walling, 327 U.S. 186, 209 (1946); see also United States v. Stuart, 489 U.S. 353, 359 (1989). 